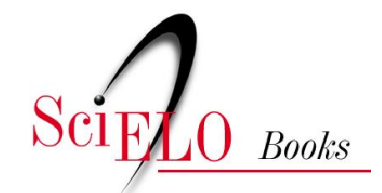

\title{
A importância da tradição pecebista
}

\author{
Raimundo Santos
}

SANTOS, R. A importância da tradição pecebista [online]. Rio de Janeiro: Centro Edelstein de Pesquisa Social, 2011, 50 p. ISBN 978-85-7982-051-9. Available from SciELO Books $<$ http://books.scielo.org $>$.

\section{@(1) $(0$}

All the contents of this chapter, except where otherwise noted, is licensed under a Creative Commons Attribution-Non Commercial-ShareAlike 3.0 Unported.

Todo o conteúdo deste capítulo, exceto quando houver ressalva, é publicado sob a licença Creative Commons Atribuição Uso Não Comercial - Partilha nos Mesmos Termos 3.0 Não adaptada.

Todo el contenido de este capítulo, excepto donde se indique lo contrario, está bajo licencia de la licencia Creative Commons Reconocimento-NoComercial-CompartirIgual 3.0 Unported. 


\title{
BIBLIOTECA VIRTUAL DE CIÊNCIAS HUMANAS
}

\author{
A IMPORTÂNCIA DA \\ TRADIÇÃo PECEBISTA
}

\section{Raimundo Santos}

centro edelstein de pesquisas sociais
www.centroedelstein.org.br 


\author{
Raimundo Santos
}

Esta publicação é parte da Biblioteca Virtual de Ciências Humanas do Centro Edelstein de Pesquisas Sociais - www.bvce.org

\title{
A importância da tradição pecebista
}

Copyright (c) 2011, Raimundo Santos

Copyright (c) 2011 desta edição on-line: Centro Edelstein de Pesquisas Sociais Ano da última edição: 2009, Fundação Astrojildo Pereira

Nenhuma parte desta publicação pode ser reproduzida ou transmitida por qualquer meio de comunicação para uso comercial sem a permissão escrita dos proprietários dos direitos autorais. A publicação ou partes dela podem ser reproduzidas para propósito não comercial na medida em que a origem da publicação, assim como seus autores, seja reconhecida.

ISBN: 978-85-7982-051-9

Rio de Janeiro

$$
2011
$$

Centro Edelstein de Pesquisas Sociais

www.centroedelstein.org.br

Rua Visconde de Pirajá, 330/1205

Ipanema - Rio de Janeiro - RJ

CEP: 22410-000. Brasil

Contato: bvce@centroedelstein.org.br 


\section{SUMÁRIO}

Nota prévia

\section{Parte}

\section{O Pecebismo Contemporâneo}

A “imagem de Brasil” da Declaração de Março de 1958 ... 1

A defesa da política nos anos de chumbo.....

Apêndice da I Parte

A presença das teses caiopradianas nos textos de Elias Chaves Neto.... 16

\section{Parte}

Novos Tempos e Outros Desafios

A importância da tradição pecebista.

\section{Apêndice da II Parte}

PD italiano, crise econômica e inovação política .

\section{Para}

Luiz Werneck Vianna

Roberto Freire 


\section{NOTA PRÉVIA}

Nossas atuais esquerdas têm muito a ganhar se interpelam a trajetória contemporânea do Partido Comunista Brasileiro (PCB). O caminho elaborativo seguido por esse partido pode lhes passar confiança para não caírem na armadilha doutrinária deixada pela extinção da URSS. Por suas dificuldades em compreender o fim do comunismo, não poucas áreas de esquerda, em vários lugares, inclusive no Brasil, foram levadas à contestação da nova época histórica e ao isolamento paralisante.

A razão de ser das nossas esquerdas está em ativarem um movimento por um novo reformismo a se construir em parceria com outros grupos e partidos, hoje existentes no país. Um reformismo - comprometido com a democracia política e o desenvolvimento com oportunidades para todos que responda ao sentido dos tempos, supere os efeitos negativos da globalização e ponha suas muitas potencialidades a serviço da vida nacional.

As correntes ligadas ao campo do marxismo político brasileiro não têm porque aceitar "marco zero" de ideias de esquerda nem aderir ao pragmatismo perigoso a que leva quem não se vale dos melhores estilos de pensar e agir deste país. No Brasil, há uma grande tradição de pensamento social e um instigante modo de ver nossas coisas a duras penas acrisolado na esquerda pecebista.

Este opúsculo tem por propósito realçar esse último tipo de patrimônio. Esperamos que estimule o leitor a avaliar o PCB não apenas por suas atuações na história, como imagem do passado, mas sobremaneira como um partido que nos traz, até os dias atuais, pontos de referência de uma cultura política de esquerda bastante útil.

\section{A Regina Cohen,}

Santiago Santos

Sérgio Botton Barcelos

Os textos A "imagem do Brasil” da Declaração de Março de 1958 e A defesa da política nos anos de chumbo, da primeira seção, sugerem duas proposições pecebistas interligadas: 1) a da centralidade da política, conquanto apenas a ação política, sob o Estado democrático de Direito, reúne energias reformistas e condições favoráveis à melhoria da sociedade, de forma sustentável; e 2) a tese de que o caminho democrático por meio da política possibilita a reestruturação progressiva da nossa economia de mercado, lembrando a propósito o que disse Habermas por ocasião da Queda do Muro de Berlim (“A economia não é um templo, mas um campo 
de testes"). Aquela segunda tese foi apresentada por uma vertente pecebista bem antiga, descrita na recensão A presença das teses caiopradianas nos textos de Elias Chaves Neto, apensada na seção inicial do volume. Está em Caio Prado Jr. - no cânone "produtivista" que o historiador constrói com sua imagem de Brasil - a melhor raiz das proposições programáticas do seu PCB (cf. PRADO JR., 2007).

O texto A importância da tradição pecebista, da segunda parte deste livro, refere-se aos desafios que os acontecimentos da época mais recente puseram às esquerdas. Em meados dos anos 1970, aos comunistas do PCB lhes foi exigido intensificar a renovação iniciada com a Declaração de Março de 1958. Este tipo de requerimento continua a inquirir o Partido Popular Socialista (PPS) e ainda as demais esquerdas, particularmente o PT.

Para ilustrar o sentido da inovação da esquerda ora em curso em outros países, o apêndice da segunda seção traz uma resenha de um texto do Partito Democratico (PD) italiano, vertente que vem fazendo esforço criativo para interferir construtivamente na vida da Itália, nesta hora da crise mundial. Este empenho para "dominar" a novíssima circunstância recebe da tradição do Partido Comunista Italiano (PCI) energias intelectualpolíticas ainda necessárias para o campo do $\mathrm{PD}$, em cuja construção os excomunistas do partido de Togliatti e Gramsci vêm tendo presença importante.

\section{Referência bibliográfica}

PRADO JR. Dissertações sobre a Revolução Brasileira. Brasília-São Paulo: Fundação A. Pereira-Brasiliense, 2007.

\section{PARTE \\ O PECEBISMO CONTEMPORÂNEO}

\section{A “IMAgem de Brasil” Da DeClaração de MARÇO DE 1958'}

D or bastante tempo, a bibliografia especializada cobrou dos comunistas a ausência de uma teoria da formação social brasileira. Essa debilidade seria responsável por vários dos seus chamados equívocos, sendo os mais criticados deles a política de frente única e a moderação ou, mais propriamente, o pendor dos comunistas à política institucional ("burguesa"). Debitavam-se à fraqueza teórica as propensões que justamente fizeram do PCB o grupo de esquerda que, afinal de contas, mais contribuiu para formar no país uma cultura política de raiz marxista.

Os comunistas chegaram àquelas duas posturas por necessidade, quando postos ante tempos difíceis: após o suicídio de Getúlio e, depois de 1964, para não falar no fim da II Guerra, ocasião em que a redemocratização requeria uma convergência com os liberais da União Democrática Nacional (UDN) daquela época. No entanto, há no PCB mais do que marxismoleninismo, ou seja, algo além da sua "péssima" teoria, como certa vez disse Hélio Jaguaribe (apud MARÇAL BRANDÃO, 1992) diferenciando dessa doutrina a prática de responsabilidade dos comunistas. Encontram-se no interior do PCB lastros intelectuais que o instigam a caminhar rumo a uma política de compromisso democrático; evolução, custosa e demorada, que se inicia com a resolução do Comitê Central de março de 1958, hoje celebrada por seus 50 anos.

A Declaração reorienta o PCB a tal ponto que ela própria chama a virada de "nova política". Que lastro elaborativo se pode divisar na resolução de 1958 além da intuição política? Não há uma teoria da "revolução brasileira" como em Caio Prado Jr. A rigor, têm-se eixos que dão o sentido geral da "nova política". Com passagens ambíguas (PASSOS GUIMARÃES,

${ }^{1}$ Este texto serviu de base para a comunicação feita pelo autor no Seminário 50 Anos da Declaração de Março de 1958, organizado pela Fundação Astrojildo Pereira, nos dias 28 e 29 de março de 2008, no Rio de Janeiro. 
1960a) - pois também escrito para atender a grupos diferenciados -, a Declaração procurou expressar as exigências do clima democrático que se afirmara no país após a posse de JK e refletir os debates sobre o XX Congresso do PCUS no PCB (1956-57); controvérsia esta, como é sabido, precisamente por ela encerrada.

Que proposições-chave compõem esses eixos? Baseiam-se numa "imagem de Brasil" que afasta o PCB do modelo da revolução nacionallibertadora da III Internacional Comunista (IC)? Um tanto dispersos, esses eixos sinalizam rumo à valorização da democracia política; paradoxo esta última, como propôs Bobbio, da "ciência política" marxista ("socialismo sem democracia" ou "democracia só se conhece no capitalismo").

A Declaração se inicia com os tópicos "O processo de Desenvolvimento Econômico do Brasil" e "A Democratização da Vida Nacional" que antecedem a um outro chamado "Crescem no Mundo Inteiro as Forças da Paz, da Democracia e do Socialismo". Comumente iniciante da escrita comunista, mesmo deslocada na Declaração, essa passagem inscreve o processo brasileiro no quadro internacionalista, do qual recebe estímulo, como veremos. À medida que avançasse no país, a revolução contribuiria para o referido complexo mundial das forças da paz, da democracia e do socialismo.

Aquele começo nos fala do Brasil contemporâneo - do pós-1930 quando se intensifica a modernização nos quadros de uma "estrutura atrasada". Ao modo da argumentação lenineana sobre a revolução na periferia capitalista, de imediato o texto diz que, nas duas décadas anteriores a 1958, "foi-se processando um desenvolvimento capitalista nacional que constitui o elemento progressista por excelência da economia brasileira". "Inelutável", continua dizendo a Declaração, esse desenvolvimento capitalista "vem-se realizando num ritmo bastante desigual" e nos anos 1950 ele não havia superado nossas "características" de "país subdesenvolvido". O avanço capitalista ocorre com a conservação em "vastas áreas" de "relações atrasadas e permanece a dependência diante do imperialismo, particularmente

\footnotetext{
${ }^{2}$ Citemos de Lênin apenas este trecho de Duas Táticas da Social-Democracia Russa: "Em países como a Rússia, a classe operária sofre não tanto do capitalismo como da insuficiência do desenvolvimento do capitalismo. Por isso a classe operária está absolutamente interessada no mais amplo, mais livre e mais rápido desenvolvimento do capitalismo. É absolutamente vantajosa para a classe operária a eliminação de todas as reminiscências do passado que entorpecem o desenvolvimento amplo, livre e rápido do capitalismo" (LÊNIN, 1905; 1975).
}

o norte-americano". Na agricultura, o capitalismo abre caminho lentamente devido à combinação, "em proporção variável", dos "métodos capitalistas" com o "monopólio da terra" e as "velhas relações semifeudais".

Nesse ponto, há indícios de mais uma remissão a Lênin. Ao acentuar o pesado fardo que o país arrastava do passado escravista-colonial, o texto de 1958 distancia o seu "desenvolvimentismo" da "sociologia da modernização" muito influente na época, justamente porque tal estruturação do moderno "à moda prussiana" aponta para a importância da democratização política do país. ${ }^{3}$

O documento vê a moderna exploração imperialista como um "pesado tributo à nação" que deprime a taxa de acumulação do país e "o ritmo do seu progresso" e influi "no baixo nível de vida da sua população". Segue-se esta proposição-chave ("isebiana", mas ressignificada pelo conceito maoísta da contradição): "À medida que a nação se desenvolve (autores isebianos falavam da nação contemporânea como "um corpo que cresce"), aguça-se o seu antagonismo com o imperialismo norte-americano". Diz-se ainda que o desenvolvimento nacional se processava "através de contradições, de avanços e recuos, mas é a tendência que abre caminho e se fortalece". A sustentabilidade das mudanças tem raiz na "contradição principal” (outra categoria maoísta) entre a nação e o imperialismo norte-americano, dinamizando o país por meio da luta de classes nas mediações de uma sociedade então já complexa. Essa lógica concretiza uma "revolução nacional" que se aprofundaria à medida que a mobilização camponesa antifeudal se alargasse seguindo a tensão entre o moderno industrializante e o atraso agrário que acompanhava a formação social.

\footnotetext{
3 “À moda prussiana" é uma expressão de Nelson Werneck Sodré que aparece em Formação Histórica do Brasil (1962). Referindo-se às tensões entre as "forças produtivas" e as "relações de produção" no mundo rural, Sodré diz: "Elas nos fornecem a caracterização, do Brasil, segundo um estudioso, de um desenvolvimento à moda prussiana, sob a ação e a influência do imperialismo. Avança sem dúvida a penetração capitalista, mas os restos feudais vão sendo conservados e o monopólio da terra zelosamente defendido" (idem: 357). Ainda acerca desse tipo de estruturação, em um texto de 1960, Alberto Passos Guimarães já escrevera: "Dois são os cursos ou caminhos possíveis do desenvolvimento capitalista no campo brasileiro: um, revolucionário, outro, reformista. (...) O proletariado e as forças mais progressistas da sociedade brasileira devem apoiar as transformações burguesas no campo que resultem na destruição dos laços com o feudalismo, que resultem na destruição das formas précapitalistas, e expressem um desenvolvimento democrático apoiado no capitalismo de Estado e na propriedade camponesa." (PASSOS GUIMARÂES, 1960b). Neste texto, Passos Guimarães chama o segundo caminho (prussiano) de "reformista" (ver SANTOS, 2007).
} 
Com essa "sociologia da modernização" visualiza-se o dinamismo que "ganhava corpo no país", tanto nas cidades (naqueles anos crescia o "fato novo" do nacionalismo) quanto no mundo rural, onde se expandia, com os sindicatos fundados pelos comunistas e as Ligas Camponesas, o movimento pela reforma agrária como nunca se havia visto. A revolução brasileira se concretizava no solo do mundo real. À medida que a mobilização se espalhasse pela sociedade civil (o desenvolvimento da luta de classes como fator de progresso à Lênin), desenhava-se o palco efetivo das operações dos protagonistas postos à frente dos grupos inovadores. Isso se aproveitassem aquele tempo bom para o agir dos revolucionários na cena política, na qual podiam atuar no dia a dia com eficácia, caso conhecessem bem a circunstância que viviam.

Nesse ponto em que se inicia a formulação da "tática" comunista (passando da dimensão do estrutural para a esfera da política), o texto sinaliza uma associação que, de certo modo, ultrapassava o nexo economiaclasses-Estado do conceito de "formação econômico-social", nexo com o qual, como se sabe, Lênin demarcava a lógica da revolução rupturista. A Declaração trazia uma outra proposição-chave - uma interface da tese sobre o desenvolvimentismo capitalista (o "elemento por excelência da economia brasileira"): "O desenvolvimento capitalista do país não podia deixar de refletir-se no caráter do Estado brasileiro, em seu regime político e na composição do governo".

Aquela sequência - Estado, regime e governo - lembra leitura de As lutas de classes na França de 1848 a 1850 e O Dezoito Brumário de Luiz Bonaparte, nos quais Marx faz suas distinções nos temas do poder e da política. Recorde-se que, ao dissertar sobre aquela conjuntura da França, o clássico mobiliza dimensões analíticas conforme configurações de "classes", "frações de classes" e "partidos". Distingue os tipos de Estado segundo a classe nele hegemônica (capitalista, socialista) das formas estatais (e de regime político) que o Estado capitalista assume em determinada formação social conforme se articulem as frações dominantes entre si e em suas relações com os grupos subalternos. Marx diferencia no Estado capitalista francês, descrito naqueles textos, as formas monárquica, republicana (e "bonapartista"). E também faz referência a configurações de governo considerando as formações partidárias. Em suma, Marx equaciona temas-chave, como o da correlação entre movimentos do estrutural e da conjuntura (a propósito, ver Engels, 1895, 1975; depois, Gramsci, 1932-34; 2007); e o da relação entre luta de classes e cena política e assim por diante.

Veja-se agora, no texto de 1958, como a seguinte série de definições conduz a uma ideia de revolução diferenciada do modelo de 1917, não obstante as ambiguidades que lhe traz a doutrina marxista-leninista:

a. Natureza do Estado. Por seu caráter de classes, diz a Declaração, o Estado brasileiro representava, então, interesses latifundiários, de setores capitalistas ligados ao imperialismo e também interesses da burguesia nacional. Ele exibia "contradições", "tipos diversos de compromisso de classe" e acordos. Era essa distinção que dava inteligibilidade à disputa dos rumos da política estatal. Para o texto, essas tensões estavam na raiz dos acontecimentos de agosto de 1954 e de novembro de 1955 ;

b. Regime político. Desde 1930, o regime político brasileiro se democratizava, mas essa trajetória, argumenta-se, "não segue o seu curso em linha reta" (Estado Novo, "ofensiva reacionária” de 1947, o golpe de 1954). A Declaração também alude à democratização no contexto rural: "A democratização do país também influi, menos acentuadamente, nas zonas rurais, onde o despotismo dos grandes senhores de terra é obrigado a ceder terreno, conquanto perdure. Os atentados cometidos pelos elementos reacionários do aparelho do Estado encontram a resistência cada vez mais eficiente das massas na defesa das liberdades e direitos constitucionais".

Nesse ponto vem uma terceira proposição definidora: "Mas o processo de democratização é uma tendência permanente. Por isto, pode superar quaisquer retrocessos e seguir incoercivelmente para diante. Vemse firmando assim, em nosso país, a legalidade democrática que é defendida por amplas e poderosas forças sociais". Aqui adquire realce a defesa da Constituição de 1946. Não obstante suas limitações, argumenta a Declaração, a Constituição refletia o sentido da derrota do nazifascismo, sendo sua vigência condição do curso democratizante. Aliás, este constitucionalismo já está no último Engels $(1891 ; 1973)$ e é bem visível no PCI de Toglatti durante o segundo pós-guerra; ${ }^{4} \mathrm{e}$

${ }^{4}$ Em meados de 1950, Elias Chaves Neto dizia que a Constituição de 1946 assegurava condições preliminares para que tivesse livre curso um processamento das reivindicações populares de 
c. Sobre configurações governamentais. Nesse tema, os autores da Declaração parecem mobilizar o esquema analítico marxiano antes aludido tirando proveito diferenciado. Eles realçam o fato de a burguesia ter se situado, à sequencia da Revolução de 1930, dentro do Estado. Esta participação nova influi na "composição do atual governo", diz o texto de 1958, assim se referindo à presidência de JK: "Em decorrência da coligação de que surgiu, o governo do Sr. Juscelino Kubitschek tomou um caráter heterogêneo, com um setor entreguista ao lado de um setor nacionalista burguês". O compromisso entre essas duas alas abre oportunidade para os revolucionários defenderem o aprofundamento dos "aspectos positivos de caráter nacional e democrático" do governo JK. Com esta leitura, o texto atualiza a luta reformista e procurar dar-lhe sentido geral.

Ao se desenvolver, continua a Declaração de Março, a pressão por mudanças na configuração do governo suscita a necessidade de se conquistar um governo propriamente "nacionalista e democrático" por ocasião das eleições. "Momento alto da luta", como certa vez as chamou um sociólogo do Rio de Janeiro, as eleições teriam como protagonistas formações duradouras: os partidos. Interessada no sistema partidário, a Declaração acrescenta: "À medida que se desenvolve o capitalismo no país, os partidos políticos brasileiros adquirem um caráter cada vez mais estável e nacional".

Ao compreender sua circunstância através dessa visão de Brasil, os comunistas chegavam a ver na democratização da vida nacional, no "ascenso do movimento operário" e no "desenvolvimento da frente única nacionalista

"modo construtivo" ("dentro dos direitos para esse fim estabelecidos em nossa Constituição - o direito de greve, de sindicalizarão, de reunião") (CHAVES NETO, 1955). E mais ainda: “Assim como a Revolução Francesa, que no século XIX trouxera enorme progresso ao mundo, aqui a defesa da Constituição é, portanto, o ponto básico de uma política que visa, pela união de todos os brasileiros, a resolver os problemas dos quais depende a nossa prosperidade" (Id.). A propósito desse ponto, ver, mais adiante, o apêndice A Presença das Teses Caiopradianas nos textos de Elias Chaves Neto.

5 Embora fuja ao escopo destas notas, citemos este trecho: "O objetivo fundamental da participação dos comunistas nas eleições consiste em eleger para os postos executivos e legislativos os candidatos da frente única, que possam fortalecer os setores nacionalistas do Parlamento e do governo. Todo o trabalho eleitoral dos comunistas, seja em âmbito nacional como em estadual e municipal, deve ser considerado parte do trabalho geral de formação e desenvolvimento da frente única, visando sempre à mudança da correlação de forças políticas e à conquista de um governo nacionalista e democrático". e democrática" bases para a concretização da revolução brasileira por um "caminho pacífico", ampliado este horizonte, diziam eles, pela distensão internacional da Era Kruschev. Isto é, por uma via de desenvolvimento normal na qual mudanças progressivas se realizariam por sucessivos governos daquela frente única. Pelo que se lê em certos pontos do texto, a formação desses governos dar-se-ia por eleições no Estado democrático de Direito.

A rigor, o curso democrático da revolução brasileira é pensado, pelo menos para boa parte do período das transformações graduais "antiimperialistas e antifeudais". ${ }^{6}$ Após esse futuro de médio ou mais dilatado prazo, a previsão pecebista decorrente da "imagem de Brasil" aqui resenhada cede o passo para um tempo descrito na tese da hegemonia proletária na frente única e na doutrina da transição socialista e assim por diante.

Não é este o lugar para nos referirmos aos cenários que, no tópico "O Caminho Pacífico da Revolução Brasileira", a Declaração desenha para a conjuntura. Em qualquer deles - giro progressista do governo JK, vitória da frente nacionalista e democrática na eleição de 1960 ou uma resistência para "impor e restabelecer" a legalidade democrática, em caso de tentativa de golpe -, os redatores daquele texto associam o seu cálculo revolucionário, para o tempo, repitamos, mais ou menos próximo, à valorização da democracia política, não obstante o seu marxismo-leninismo. A propósito dessa compreensão da democracia política, quase ao final do seu livro de 1962, Sodré dirá:

A defesa do regime democrático, no processo da Revolução Brasileira, não se prende, assim, ao supersticioso respeito a uma legalidade qualquer, mas na compreensão de que a democracia é o caminho apropriado ao seu desenvolvimento. Não interessa ao nosso povo, evidentemente, uma legalidade qualquer, mas o regime democrático efetivo cujo conteúdo esteja intimamente ligado ao desenvolvimento de alterações econômicas, políticas e sociais capazes de afetar profundamente o país e corresponder ao avanço das forças produtivas que impõem modificações radicais nas relações de produção.

\footnotetext{
${ }^{6}$ Alberto Passos Guimarães refere-se a esse tempo previsível como sendo um "período intermediário", "específico da revolução brasileira", no qual "uma sucessão de governos" poderia empreender reformas progressistas "nos quadros do regime vigente" (capitalista) (PASSOS GUIMARÃES, 1960a; ver também SANTOS, 2007).
} 
Bem depois, na segunda metade dos anos 1970, esse fio será retomado em círculos dirigentes do PCB. Uma jovem ensaística pecebista vem diferenciar nossa modernização da via clássica de revolução burguesa e chamar atenção para o fato de que, aqui, a relação entre economia e política obedece a uma lógica de natureza "muito mais irregular", podendo-se também imaginar a revolução burguesa brasileira como uma "revolução passiva".

Alguns autores dessa tendência realçam o sentido não recessivo do regime de 1964, conquanto ele modernizara, de modo conservador, tanto a economia como a própria agropecuária. $\mathrm{O}$ dado estratégico passa a ser a relação entre o crescimento das forças produtivas nacionais promovido pelos governos militares, e a natureza da transição democrática sob o impulso das modernizações, mas dependente da ação oportuna dos atores políticos (VIANNA, 1983). Essa valorização da redemocratização decorria de uma releitura da modalidade sob a qual o país se industrializara tardiamente por via autoritária sem a classe econômica ter construído uma institucionalidade política adequada (idem). À hora do colapso do regime de 1964, formar-seia uma situação na qual a democratização política, cada vez mais em rápido andamento depois da anistia de 1979, não só viria concluir o período ditatorial como também poderia trazer - dizia um outro autor - "consequências progressistas de efeito quase revolucionário" (KONDER, 1984).

Essa ensaística significa um outro grande passo no plano da "formulação da política" pecebista contemporânea. Em 1958, a Declaração de Março havia rompido com o viés estagnacionista que até ali marcara a "imagem de Brasil" dos comunistas, passando a associar ao crescimento econômico um processo de complexificação social e a tendência do país rumo à democratização política. ${ }^{7}$ O novo registro de meados dos anos 1970

\footnotetext{
${ }^{7}$ Enquanto a orientação pecebista oficial atribuía as causas do dogmatismo persistente no PCB a traços de formação, Armando Lopes da Cunha apontava noutra direção: "Na base de tal concepção, dizia ele, por ocasião da controvérsia sobre o stalinismo, está uma outra - também expressamente formulada em nosso Programa (de 1954), a saber: a de que o processo de desenvolvimento do país e a conquista de sua plena independência só serão possíveis após a derrubada do 'atual' governo" (o segundo governo Vargas - RS). (...). Rompendo com a tese da transformação do Brasil em colônia dos Estados Unidos, prosseguia Lopes da Cunha: "Não há mais dúvida de que o país pode se desenvolver e caminha rapidamente para sua independência nacional sem uma prévia derrubada do 'atual' governo, e não há mais dúvida simplesmente porque isto está acontecendo sob nossos olhos. (...). A necessidade de modificarmos nossas concepções programáticas é, portanto, patente, como patente é também que muito se pode avançar no sentido da independência e do progresso bem como da própria
}

sugeria que se tivesse uma ideia de mudança social bem distanciada do arraigado axioma atraso-miséria-revolução. Daí se tendia a ver o processo mudancista como uma gramsciana "guerra de posições", no dizer de uns; ou, ainda, como preferiam outros autores, a pensá-lo em termos de um processo de transformações duradouras sob forma de um "reformismo forte" progressivo à medida que a democracia política se enraizasse cada vez mais no país.

\section{Referências bibliográficas}

CHAVES NETO, Elias. Política de União Nacional. Revista Brasiliense n. 1, set./out. 1955.

ENGELS, F. La crítica al Programa de Erfurt (1891). Madri: Anagrama, 1973.

. "Introducción" a La Lucha de Clases en Francia de 1850 a 1852 (1895). In: MARX, C., e ENGELS, F., Obras Exigidas, v. 1, ed. Progresso, Moscou, 1975.

GRAMSCI, Antonio. Notas sobre Maquiavel, a política e o Estado, Civilização Brasileira: Rio de Janeiro, 3. ed., trad. Luiz Sérgio Henriques, Marco Aurélio Nogueira e Carlos Nelson Coutinho, 2007.

KONDER, Leandro, O atraso é tanto que Governo Tancredo Neves terá efeito quase revolucionário. Tribuna da Imprensa, 24 de setembro de 1984.

LÊNIN, W. Dos Tácticas de la Socialdemocracia Rusa. In: Lênin, W. Obras Exigidas en Doze Tomos, v. 2. Moscou: ed. Progreso, 1975.

LOPES DA CUNHA, Armando. O Programa e o Caminho do Desenvolvimento do Brasil. Voz Operária, 27 de outubro de 1956.

MARÇAL BRANDÃO, Gildo. Partido Comunista, Capitalismo $e$ Democracia, São Paulo, USP, 1992. Tese.

modificação do governo nos quadros da atual Constituição... nossa tática sofrerá profundas mudanças e permitirá a reunião de imensas forças dispostas a combater o imperialismo norteamericano e impulsionar o progresso do país." Outro ponto novo: "Passamos a ter que apresentar soluções positivas para os problemas brasileiros e deixaremos de criar dificuldades para a unidade de ação em prol da independência como por vezes tem ocorrido por estarmos imbuídos das mencionadas ideias programáticas que condicionam a tática estreita, sectária e exclusivista" (LOPES DA CUNHA, 1956) 
PASSOS GUIMARÃES, Alberto. Uma Falsificação e Vários Erros Crassos na Questão das Etapas. Novos Rumos, Rio de Janeiro, 22 a 28 de julho de 1960a.

As Três Frentes da Luta de Classes no Campo. Novos Rumos, Rio de Janeiro, 22 a 28 de julho de 1960b.

SANTOS, Raimundo. Agraristas Políticos Brasileiros. Brasília: Fundação Astrojildo Pereira-Nead-IICA, 2007.

SODRÉ, Nelson Werneck. Formação Histórica do Brasil. Brasiliense: São Paulo, 1962.

VIANNA, Luiz Werneck. O Problema da Cidadania na Hora da Transição. Rio de Janeiro: Série IUPERJ, 1983.

\section{A DEFESA DA POLÍTICA NOS ANOS DE CHUMBO}

- leitor tem diante de si um texto expressivo do exemplo brasileiro de um partido revolucionário - o PCB - que se converte em partido da política. Os comunistas do PCB assentaram neste país uma tendência à identificação cada vez mais "sem reservas com o Estado democrático de Direito, sem o abandono de objetivos reformistas muito além do status quo", como propõe Habermas às esquerdas. O PCB caminhou muito nessa direção antes do exílio do Comitê Central de meados dos anos 1970, ocasião em que parte dele intensificaria sua aproximação com essa cultura política de esquerda. Relembremos alguns registros que indicam esse rumo:

1) Bem distante, Caio Prado, opondo-se ao queremismo de Vargas, tornou-se conhecido defensor da redemocratização no final do Estado Novo;

2) Há textos pecebistas que valorizam o tempo democratizante subsequente à eleição de JK;

3) As Teses e a Resolução do V Congresso de 1960 descrevem cenários de governos reformista-democráticos concretizáveis mediante a política de frente única;

4) Em maio de 1965, o PCB aprovou resolução pondo no centro da resistência ao regime militar a defesa das liberdades; e

5) A resolução do Comitê Estadual do PCB da Guanabara, de março de 1970, objeto desta apresentação, é ponto importante nessa trajetória.

Esse último texto avalia o percurso do regime de 1964, especialmente o novo curso reacionário trazido pelo Ato Institucional $\mathrm{n}^{\circ} 5$, de 13 de dezembro de 1968. Elaborada para se "ter domínio", mediante previsão e perspectiva, do terreno sumamente adverso dessa época, a resolução traz uma precisa análise de conjuntura, construída por quem lera os escritos de

${ }^{1}$ Apresentação do documento "Resolução Política do Comitê Estadual da Guanabara do PCB" (março de 1970), publicado na coletânea Manifestos Políticos do Brasil Contemporâneo, Lincoln de Abreu Penna (Org.), editora E-Papers, Rio de Janeiro, março de 2009, 308 p 
Marx e Engels sobre a França de 1848 a $1852 .^{2}$ O seu redator tanto compreendia bem as observações dos clássicos sobre as formas do Estado Capitalista (republicana, bonapartista) quanto sabia o crucial que era o tema da cena política. Esta última questão sempre desafiou os publicistas revolucionários quando buscavam, na superfície da vida corrente, visualizar a presença do econômico, da determinação "mais estrutural", dizia-se então, a perpassar maior alcance ao agir imediato e às ações parciais.

Cabe aqui um parêntese para aludir às intervenções de Alberto Passos Guimarães por ocasião do V Congresso de 1960. Este autor extraía do tema da "etapa" um modo especial de conceber a revolução na circunstância brasileira. A distinção das fases revolucionárias - o curto, o médio e o longo termo, este pertencente ao domínio da doutrina - importava numa questão, sustentava Passos Guimarães, decisiva conquanto habilitava o PCB como ator real. Já o publicista de 1970 se impunha este desafio: a partir da caracterização do regime militar enrijecido depois de 1968, divisar, para a conjuntura e o futuro próximo, contornos de movimentos, visíveis e latentes, da(s) cena(s) política(s), indicativos de possibilidades para a ação oposicionista.

Aqui entrava o tema das formas da "dominação estatal de classe" (sic). ${ }^{3}$ O publicista redator da resolução de 1970 centralizava sua atenção na "máscara de ferro" (expressão de Werneck Vianna para o Estado Novo) do regime de 1964. Chamá-lo de "fascista" não expressava doutrinarismo, pois não se dava acepção formal à conceituação (o fascismo como decorrência do grande capital, imposto à margem da sua história política). Ao contrário, dizia-se na resolução, radicar o fim da ditadura no primarismo ("que vê as esperanças do êxito de uma política revolucionária unicamente no caos e na catástrofe da política econômica das classes dominantes") só levava à ilusão de uma "derrota fácil" (sic) do regime e ao imobilismo da resistência.

O publicista reconhecia que, após o AI-5, a ditadura passara a abafar a vida nacional de modo quase total. No entanto, como falava de um lugar

${ }^{2}$ Em pequena nota à sua republicação (1981), Armênio Guedes revelou ter elaborado o texto da resolução, o qual foi aprovado "por unanimidade na Comissão Política e no Comitê Estadual, praticamente sem qualquer emenda" (cf. GUEDES, 1981).

${ }^{3}$ Essa leitura da obra política de Marx já aparece nas Teses do V Congresso. Com proveito, fazia-se neste texto a distinção entre Estado (classe), regime (articulação entre frações de classe) e governo (composição de forças político-partidárias e associativas). Essa construção marcaria, no PCB de 1960, a definição da tática imediata em associação com o objetivo último: alcançar um governo nacionalista-democrático reformista. de partido (propenso a agir com eficácia), se fixava no modo como nascera o regime de 1964 e no processo contraditório do seu enrijecimento subsequente ao AI-5. Daí a leitura dos anos de chumbo feita pelo publicista não conferir "permanência estrutural" à "máscara de ferro" do regime, ante a qual nada se poderia fazer.

Quando chama a fase terrorista da ditadura de "processo de fascistização", a resolução fixa atenção em dois pontos: a) no "condicionamento" antidemocrático do estrutural (monopolização, contração do mercado nacional, etc.) e no desenvolvimento econômico (a transmitir alguma força ao regime); e $b$ ) nas peculiaridades que a montagem do projeto fascista assumia entre nós. Visto dessas duas dimensões, nada garantia que o regime se tornasse uma "contrarrevolução permanente".

Ao contrário, mesmo duríssima, a ditadura caminhava, já então, para a instabilidade enquanto o campo oposicionista tendia a se adensar. Era possível se desenvolver uma luta contra a ditadura em moldes de uma "guerra de posições" gramsciana, com três momentos: a época de resistência (sobremaneira naquela fase terrorista da ditadura), o momento de isolar o Regime de Abril e, depois, a hora da sua derrota.

Tais cenários traduziam perspectiva de combate à ditadura por meio do único instrumento viável: a política, esfera na qual as possibilidades de atuação do ator sagaz eram bem maiores.

O que permitia essa previsão em hora sombria? O redator da resolução divisava a cena política através de uma atenta interseção entre o econômico (e suas determinações) e a esfera do político-superestrutural (e as muitas iniciativas dos atores). O publicista de 1970 via o "processo de fascistização" a partir da dialética das contradições do regime e das suas crises, sucessivas à medida que a radicalização reacionária avançava. Tal curso, acidentado e complexo, iria dinamizar, com avanços e recuos, o campo oposicionista posto no horizonte o objetivo último da formação de uma frente única que venceria a ditadura. O palco decisivo da "guerra de posições" a se armar no curto prazo demandava paciência e grande esforço no agir possível. ${ }^{4}$

${ }^{4}$ Na sequência da resolução, o Comitê Central aprovou (1971) dois documentos: um, sobre os
entendimentos políticos ("nos mais diferentes níveis") e um outro, registrando a acumulação de entendimentos políticos ("nos mais diferentes níveis
ações parciais nas esferas sindical e associativa. 
Desvelava-se, assim, o ponto de Arquimedes da resistência antiditatorial. O recurso ao conceito de "processo de fascistização" levava à identificação da fratura incurável do regime. Desde 1964 houve resistência ao avanço reacionário. Já no pleito para governador de 1965, a ditadura foi derrotada em Minas Gerais e no Rio de Janeiro e, em 1967, sentiu-se ameaçada pelas reuniões da Frente Ampla (a convergência GoulartLacerda-JK) e as proibiu. A princípio, o impulso da oposição tinha epicentro no mundo político, no interior do qual se moviam operadores atentos aos conflitos crescentes do regime com a "velha classe política" (sic). Com o tempo, por entre linhas de insatisfação com os males do regime, iria ganhar corpo o espírito da "rebeldia brasileira".

O cronista das marchas e contramarchas daquela radicalização reacionária faz registro acurado. Dizia que o Regime de 1964 não havia conseguido organizar base de apoio sólida devido a sua natureza autoritária. E ainda: à proporção que o seu núcleo duro levasse adiante a fascistização perderia mais aliados, sendo obrigado a substituir áreas políticas por quadros tecnocratas, insulando-se cada vez mais. Inteligível, assim, o nexo entre a defesa das liberdades, a atuação nas eleições, mesmo controladas (como disse o sociólogo do Rio de Janeiro aludido, a "forma alta de luta") e a afirmação do movimento democrático brasileiro.

Aliás, um outro parêntese. O caminho indicado na resolução de 1970 diferia muito daquele que Florestan divisava nos seus escritos quase dessa mesma época. O sociólogo vê cristalizar-se no pós-13 de dezembro de 1968 o processo de autocratização completa do sistema político como uma espécie de "lei de ferro" do capitalismo dependente. ${ }^{5}$ O texto do PCB da Guanabara não previa um fechamento de horizonte como esse, mas uma larga caminhada, pressuposto o papel da política como meio apropriado, conquistados mais e mais espaços democráticos, para o combate à ditadura. Os comunistas do PCB iriam operar no campo da política com desenvoltura. Naquela hora adversa, perceberam que, sem mobilizar o mundo político existente (o PTB, o PSD; depois o MDB), o caminho à frente se tornava turvo.

$\mathrm{O}$ ponto desenvolvido por Passos Guimarães no V Congresso de 1960 será reposto após o AI-5. O publicista de 1970 iria pela contramão em relação a vários intelectuais que então falavam do fim próximo do regime

${ }^{5}$ Florestan não dispunha da vantagem, como A. Guedes, de estar situado, por assim dizer, na dimensão da práxis (a propósito deste tema, ver VÁZQUEZ, 1978). de 1964 dado o cenário da economia. Recessivo nosso capitalismo desde os últimos anos de Goulart e inviável novo ciclo econômico, os golpistas de 1964 não teriam fôlego. O que singulariza a resolução de 1970 é justamente a valorização do campo da política, nos anos de chumbo terríveis. Ela tem muita atualidade nestes nossos outros dias de corrosão da política, agora por conta do paneconomicismo antipopular e anti-institucional.

\section{Referências bibliográficas}

GUEDES, Armênio. "Introdução" a Resolução do Comitê Estadual do PCB da Guanabara, março de 1970. In: Temas de Ciências Humanas n. 10, São Paulo, 1981.

VÁZQUEZ, Adolfo Sánchez. Ciencia y Revolución (El marxismo de Althusser), Grijalbo, México, 1978. 


\section{APÊNDICE DA I PARTE: \\ O PECEBISMO CONTEMPORÂNEO}

\section{A PRESENÇA DAS TESES CAIOPRADIANAS nOS TEXTOS de Elias Chaves Neto ${ }^{1}$}

$\mathrm{N}$ o caso de um intérprete do Brasil, como Caio Prado Jr. - econômico em citações de autoridade, aparentando enquadramento na linguagem marxista-leninista -, o realce da presença em seus textos de alusões à história comparada pode não apenas trazer elementos úteis para a avaliação das suas raízes intelectuais, como ainda vir a estimular conjeturas sobre o sentido publicístico da sua obra e, especialmente, da sua ideia da Revolução Brasileira.

Mas é preciso não se esquecer de situar o autor em seu campo e não diminuir o influxo invasivo que a revolução russa e a URSS, com o marxismoleninismo, exerceu na longa trajetória do seu PCB. Como se sabe, esse marxismo do Movimento Comunista Internacional não apenas interditou a elaboração dos primeiros anos e travou o PCB na virada de 1945, como ainda adiou, e por muito tempo, o uso dos escritos seminais de Lênin sobre a revolução russa de 1905, particularmente acerca do prussianismo, os quais só começariam a ser trabalhados por autores pecebistas proveitosamente mais tarde.

\footnotetext{
${ }^{1}$ Este texto foi redigido originariamente em 2000. Sua inclusão neste volume visa apresentar traços da "corrente caiopradiana" por meio de uma recensão de escritos de Elias Chaves Neto do período 1955-1963. A militância propriamente partidária de Caio Prado é bem visível na década de 1940, quando o historiador teve papel relevante no movimento dos grupos de esquerda que buscavam aliar-se aos liberais da União Democrática Nacional (UDN) para por fim ao Estado Novo e democratizar o país. Foi candidato derrotado às eleições da Constituinte de 1945 , sendo eleito em seguida deputado à Assembleia Constituinte do Estado de São Paulo. Em 1947, Caio Prado publicou na Tribuna de Debates do IV Congresso do PCB, o artigo "Os Fundamentos Econômicos da Revolução Brasileira” (PRADO JR., 2007). Depois vieram o isolamento e os anos de perseguição aos comunistas. Caio Prado reaparece na cena pública a partir da fundação da Revista Brasiliense, em 1955. Em 1960 e 1966, escreve textos para o V e VI Congressos, realizados, respectivamente, em 1960 e 1967. Uma versão do presente texto circulou no grupo de pesquisa "Questão Agrária e Política" (UFRRJ-CPDA) e integra o livro Caio Prado Jr. na Cultura Política Brasileira, Rio de Janeiro: Faperj-Mauad, 2001.
}

A forte raiz marxista-leninista do PCB não desencoraja atentar para os apelos que publicistas seus fazem a outros modelos e ver melhor como tais recursos aparecem em alguns deles configurando matizes que se acrisolam no pecebismo contemporâneo. Essas interações vão desde os influxos dos escritos dos clássicos sobre as revoluções até influências intelectuais propriamente ditas. Afora os impactos das revoluções chinesa e cubana, esta mais nas dissidências do pós-64, nota-se uma pequena, mas recorrente, presença do PCI em alguns ambientes do PCB, após o XX Congresso do Partido Comunista da União Soviética (PCUS) de 1956. Às vezes ela aparece sob forma de materiais italianos publicados na imprensa partidária, às vezes como citações em militantes que trazem em seus textos argumentos do "caminho democrático ao socialismo" então proposto pelo PCI. Mais tarde, chegaria o influxo, por assim dizer, das reflexões do "pequeno marxismo" sobre as experiências de modernização pelo alto (Lênin, acima citado, e também Lukács); e da teoria gramsciana da "revolução passiva", esta nova presença italiana já no contexto do eurocomunismo de meados dos anos 1970.

No caso de Caio Prado, comunista que não deixa a originalidade da sua interpretação de Brasil desaparecer sob os cânones da doutrina marxista-leninista, chama a atenção a comparação que aparece em seus textos entre o nosso industrialismo e as vias europeia e americana de constituição do capitalismo, referidas como modelo de generalização do progresso (material e espiritual) e de incorporação e homogeneização social. Também desperta interesse certa inspiração dos excursos de Caio Prado Jr. acerca do industrialismo brasileiro no take-off do capitalismo das ex-colônias inglesas. Este emblema americano constitui uma presença estratégica a percorrer os textos caiopradianos, visível quando se lê a versão do seu principal divulgador, Elias Chaves Neto, à hora em que este jornalista trata de fundamentar as controvérsias que mantém com o PCB pelas páginas da Revista Brasiliense, justamente se apoiando no mestre, parente e amigo Caio Prado.

Foi Prestes quem primeiro mencionou a presença de Elias Chaves Neto no reaparecimento da "corrente caiopradiana" em meados dos anos 1950. Ele chamava a atenção para o artigo "Política de União Nacional", publicado no primeiro número da Revista Brasiliense, de autoria daquele que vai se por à frente da nova publicação como seu diretor-responsável por todo o decênio de 1955/64: Elias Chaves Neto. A interpelação do secretário- 
geral do PCB prenunciava o destino que iria ter a revista de Caio Prado Jr. como lugar de exposição daquela vertente pecebista que, como a dos renovadores "revisionistas" de 1956/57, tampouco teria livre passagem no partido comunista. Prestes advertia a Revista Brasiliense pelo seu envolvimento com o que ele chamava de "nacional-reformismo", naquilo que ecoava os novos tempos que estavam sendo anunciados tanto pela Cepal (Celso Furtado já havia antecipado o argumento de Formação econômica do Brasil, em 1954, com a publicação de A economia brasileira) quanto pela publicística de uma intelligentsia de centro-esquerda que já vinha editando os Cadernos do Nosso Tempo, dando os primeiros passos para fundar o Iseb.

Hélio Jaguaribe, o militante-fundador do Instituto Brasileiro de Estudos Sociais e Políticos (Ibesp), também escrevera nessa mesma época dizendo que Caio Prado era "o único teórico marxista do Partido Comunista Brasileiro". Como membro qualificado daquela instituição precursora do Iseb, falando do vazio bacharelesco da intelligentsia brasileira, Jaguaribe dizia então com toda severidade: "A literatura morreu nos anos 1940. Como só havia literatura, nada restou para lhe tomar o lugar, carecendo, ainda, de repercussão nos meios intelectuais, o esforço filosófico que vêm empreendendo os grupos indicados" (JAGUARIBE, 1952; 1957). O isebiano referia-se aos ecos no Brasil do neotomismo, do existencialismo cultural e do neopositivismo; o marxismo incluído, representado por um Caio Prado Jr. que se mantinha, explicava ele, estritamente fiel à ortodoxia partidária, "conservando uma posição epistemológica e uma interpretação sensualista da realidade tipicamente oitocentista" (idem). E mais: "É de crer-se, no entanto, que esse esforço filosófico logre afirmar-se e desenvolver-se, dando ensejo ao aparecimento de uma literatura de ideias, apta a responder às grandes questões irresolvidas, em nossa atmosfera espiritual. Neste caso, tudo indica que se processará, finalmente, a fundação de uma cultura brasileira, herdeira da europeia, integrada no espírito ocidental, mas vinculada à realidade do Brasil e representativa de suas necessidades" (idem).

Diferente do seu mestre Caio Prado Jr. que, em artigos escritos para a revista, falava como um publicista "temático", Elias Chaves Neto aparecia nas páginas da Revista Brasiliense mais como um militante. Paulo Sérgio Pinheiro, o organizador dos seus textos, chega a dizer que "Se os conflitos do Partido com o historiador Caio Prado Júnior foram provocados por suas revisões precursoras das bases de interpretação da sociedade brasileira - feudalismo, revolução brasileira, burguesia nacional -, com Elias Chaves Neto os desencontros são provocados por suas análises de conjuntura nada convencionais" (PINHEIRO, 1982: 14; in CHAVES NETO, 1982).

Além de A Revolução Brasileira (1966) que, como se sabe, fora sua contribuição ao VI Congresso de 1967, Caio Prado Jr. só escrevera de modo mais incisivo sobre a política pecebista nas Tribunas de Debates do IV Congresso de 1947 e do V Congresso, de 1960. Tem-se a impressão de que esse tipo de comportamento "estritamente disciplinado" ainda reflete os dissabores da derrota do grupo caiopradiano na controvérsia em torno da estratégia de resistência ao Estado Novo. Mas há quem cobre do autor o fato de ele ter feito a crítica de 1966 em público, sem que o PCB pudesse se defender em condições tão amplas como as da publicação legal daquele livro (MALTA, 1966).

De qualquer modo, também comunista disciplinado, em vários artigos publicados na Revista Brasiliense, Elias Chaves Neto se confrontava abertamente com o PCB, ora tentando combinar os temas do caminho revolucionário e da democracia, em formulação pecebista, ora discordando do seu partido nas questões correntes.

Em suas memórias, Elias Chaves Neto reconhece que a fundação da Revista Brasiliense dava curso a um movimento de redefinição da orientação comunista que tivera início logo após a morte de Getúlio. Ele se referia a um passo anterior do "grupo caiopradiano" que consistira em convencer o historiador a disputar a cadeira de Economia Política na Faculdade de Direito de São Paulo, para o qual iria escrever a tese Diretrizes para uma Política Econômica Brasileira, em 1954. Logo depois, a Revista Brasiliense assumiria para si a tarefa de estimular investigações em busca de "soluções adequadas" aos problemas brasileiros, fazendo contraponto com as ilusões sobre o nosso progresso, como diziam os organizadores da revista na sua apresentação, notável em muitos campos, mas que "mal dissimula"(va) nos grandes centros urbanos o atraso econômico do país (BASTOS, 1955). Revelando marca caiopradiana, a apresentação da Revista Brasiliense acrescentava que o tema do atraso seria bem compreendido à medida que se avançasse numa teorização capaz de caracterizar a natureza e o sentido da industrialização substitutiva ("em que fomos compelidos a prover nós mesmos as nossas necessidades"), mas, ecoando as teses do historiador, a considerava insuficiente para atender às 
exigências de bem-estar, particularmente o de "densas camadas" da população rural em estado de extrema pobreza, à margem do surto econômico e industrial (idem).

Elias Chaves Neto verbaliza na revista as posições do PCB, com elas debatendo, apelando, inclusive, para outras construções intelectuais "sem se isolar das tradições do pensamento como as liberdades democráticas" (PINHEIRO, 1982; in CHAVES NETO, 1982). Quanto à política nacional daquela época, o articulista da Revista Brasiliense reclamava desde o entreguismo da "revolução desenvolvimentista" de JK (sic) até o confronto exacerbado entre João Goulart e a oposição, luta que o preocupava, como também a seu mestre, por ela estar obscurecendo a adoção de diversas "medidas concretas" que o Presidente da República poderia tomar em defesa dos interesses populares. ${ }^{2}$

No entanto, o que interessa chamar a atenção são os apelos a outras referências que aparecem nos textos de Elias Chaves Neto sugerindo traços da publicística caiopradiana. Neste sentido, adquirem particular interesse o compromisso do autor com o projeto da Revista Brasiliense e a sua completa identidade com as teses do historiador a ponto de se atribuir nessa relação apenas o papel de jornalista, reconhecendo em Caio Prado Jr. a função propriamente intelectual (CHAVES NETO, apud PINHEIRO, 1982). Essa associação nos permite visualizar nos artigos de Elias Chaves Neto publicados na Revista Brasiliense o sentido da presença do "grupo caiopradiano" no mundo pecebista do pré-64. Ao polemizar nesses textos com seu partido, Elias Chaves Neto alude, com postura bem pecebista, à dimensão da política corrente do $\mathrm{PCB}$, ponto em relação ao qual, como à época disseram alguns dos seus críticos, Caio Prado Jr. se manteria "ausente".

No artigo que escreve para o primeiro número da Revista Brasiliense ("Política de União Nacional"), Elias Chaves Neto se referia às "novas

\footnotetext{
${ }^{2}$ Em um artigo do final de 1963, Elias Chaves Neto também cobrava de Jango "uma posição francamente de esquerda" (e que pusesse "fim ao palavreado nacionalista" e à conciliação de interesses da burguesia nacional com o imperialismo"). Leia-se estes dois trechos bem caiopradianos: "É nesta antítese (da polarização oposição-governo da época) que se processa a vida política do país, postos de lado e esquecidos os problemas concretos que afetam de forma tão dramática a vida do nosso povo". Em outro, reclamava do caráter ainda personalista da política brasileira: "É o que explica o fato das grandes questões nacionais serem debatidas fora dos quadros da política partidária e o estranho resultado de eleições que não revelam um pronunciamento da opinião pública em face desses problemas" (CHAVES NETO, 1963b).
}

concepções, as quais iam abrindo dificilmente o seu caminho" (CHAVES NETO, 1977: 146). Embora não haja referência específica, o autor certamente está aludindo a outras áreas pecebistas, aparentemente distantes do grupo da Revista Brasiliense que, logo depois, irão ter importância nos debates pecebistas sobre o XX Congresso do PCUS (SANTOS, 1988). Em suas intuições, Chaves Neto caminhava no mesmo rumo dos renovadores de 1956/57, expondo uma formulação em alguns pontos diferenciada dos padrões da mundo comunista da época, tentando renovar a orientação pecebista. Ele mobilizava as proposições caiopradianas e recorria aos ensinamentos da crise do estalinismo que extraía da tese da via pacífica e do caminho democrático ao socialismo proposto pelo PCI.

Uma das características dos textos de Elias Chaves Neto já foi registrada fora do ambiente pecebista. Na apresentação da coletânea Sentido Dinâmico de Democracia (1982), o mesmo Paulo Sérgio Pinheiro aponta convergência de Elias Chaves Neto com o que, no começo dos anos 1960, vai ser conhecido como crítica do populismo e faz esta indicação:

Os artigos de Elias Chaves Neto permitem ver a vertente de defesa de nacionalismo que, graças a sua insistência na democracia, não perdia de vista a oposição entre capital e trabalho, que algumas vezes parecia ter desaparecido da pregação nacionalista (PINHEIRO, 1982; in CHAVES NETO, 1982).

\section{O autor acrescenta:}

E fica claro que para ele a preocupação pela transformação de uma economia que atendesse às prioridades e às necessidades da maioria da população brasileira nada tinha a ver com uma concepção autoritária do Estado (idem).

É ainda Paulo Sérgio Pinheiro quem diz que a ênfase no tema da democracia aparece em Elias Chaves Neto - este comunista "bem estranho", "trânsfuga da classe dominante", "convertido tardio" e amigo inseparável de Caio Prado Jr. (sic) - como uma antecipação dos debates e da aceitação mais plena e bem posterior do valor da democracia entre os setores das esquerdas marxistas brasileiras (idem). Como costuma acontecer em elaborações gestadas como dissidências no interior de uma ortodoxia cultural, na qual ainda se mantêm ligados os seus autores críticos, a ambiguidade "forçada" pela tradição que se vê nos textos de Elias Chaves Neto se manifesta não só na linguagem marxista-leninista como nos temas que ele introduz nos 
artigos publicados na Revista Brasiliense. Por exemplo, leem-se ali a valorização da democracia política e a defesa do socialismo real; ao mesmo tempo em que o autor fala de "revolução democrática", inclusive ao modo do PCI, também alude ao proletariado como classe universal e assim por diante.

Mesmo com argumento problemático, Elias Chaves Neto se volta para a "questão comunista" daquele pré-64, procurando fundir sua formulação da estratégia revolucionária com as teses que extraía da obra caiopradiana. São sugestivas as suas tentativas de associar ao construto de Caio Prado Jr., primeiro, as bandeiras libertárias de 1789 (especialmente o papel transformador que divisava na vigência efetiva da Constituição de 1946 em meados dos anos 1950) e, depois, a tese tocquevilleana sobre o americanismo. Poder-se-ia dizer que tais referências sugerem contornos da ideia caiopradiana da Revolução Brasileira. Há tanto adiantamentos "precursores" nos quais Chaves Neto acolhia a ideia da via democrática ao socialismo imaginada por Togliatti como proximidade com a chamada "tática das soluções positivas", proposição reformista que apareceu nos debates de 1956/57 e circulou, por algum momento, no PCB, sendo inclusive retomada durante o V Congresso de 1960 (COELHO, 1960).

Convém sublinhar que os textos de Elias Chaves Neto não conformam uma dissertação própria e apresentam aspectos indefinidos. Mesmo que descontínuas, certas passagens dos escritos de Elias Chaves Neto revelam contornos da corrente caiopradiana notada por Prestes no seu artigo dedicado ao aparecimento da Revista Brasiliense. Especialmente a passagem na qual o jornalista recorre às teses do seu mestre sobre a via política de constituição do nosso capitalismo, pondo ênfase, não tanto na sua "operacionalização" com vistas à análise da conjuntura nacional (como fazia Caio Prado Jr. em textos escritos para a revista), mas procurando realçar a função positiva que as demandas populares desempenhariam em um contexto democrático.

Esse tipo de leitura dos textos de Elias Chaves Neto sugere que, quando utiliza a teorização caiopradiana para sustentar seus argumentos, o editor da Revista Brasiliense seguia os dois fios sempre presentes na obra do historiador. O primeiro deles, o da insistência na reversão do sentido de um industrialismo aqui se organizara por contingência da crise de uma estrutura econômica voltada para fora. $\mathrm{O}$ segundo, o da "miséria e da fome da grande massa popular", Chaves Neto também o enfatizava como questão nacional estratégica de cuja solução dependiam as possibilidades do movimento de renovação da vida econômica da nação (CHAVES NETO, 1956a). Aliás, respondendo à inquirição que, no artigo já citado, fizera-lhe Prestes por ter buscado a chave da compreensão dos problemas nacionais na obra histórica caiopradiana (e não no marxismo), ele dizia que, de fato, ali havia encontrado a causa da debilidade do mercado interno, uma vez que "somente a história nos pode revelar o sentido íntimo dos fenômenos dos quais a observação imediata nos revela apenas as aparências" (idem).

Já no primeiro artigo escrito para a Revista Brasiliense, Chaves Neto aludia ao exemplo americano da prosperidade das indústrias do Leste, obtida no século XIX, quando se estruturara um mercado interno complementar, aberto a Oeste do país. Ele lembrava que haviam sido justamente a distribuição de terras além do Mississipi, conforme o programa farmer de Lincoln, a contínua expansão territorial e a abertura de grandes mercados consumidores que desencadearam o desenvolvimento industrial daquele país. Cite-se o autor:

Entretanto, os mesmos elementos que fizeram a grandeza norteamericana atuam hoje no caso brasileiro: a existência de um mercado interno, suscetível de assegurar a uma indústria nacional crescente longos anos de prosperidade. É verdade que esse mercado interno precisa ser estimulado e até criado. Mas é a luta do nosso trabalhador por melhores condições (pela reforma agrária no campo e melhores salários nos centros urbanos) que vai criar esse mercado do qual depende a prosperidade dos negócios brasileiros (CHAVES NETO, 1955).

Esse mesmo tema do Oeste novamente se faz presente em um dos últimos artigos de Elias Chaves Neto. Com efeito, em "A Grande Revolução", o divulgador de Caio Prado Jr. mencionava as reflexões de Tocqueville sobre o Oeste (no qual o pensador político francês via o limite último da democracia) e o profundo sentido de igualdade da sociedade americana. Elias Chaves Neto ainda lembrava que Tocqueville chegara a ver o igualitarismo americano como um fato social "que não poderia ser mais detido". Ele seguia sua observação com esta passagem do próprio Tocqueville: "Parece-me fora de dúvida que mais cedo ou mais tarde chegaremos como os americanos à igualdade completa de condições". "O que me será dado esperar ou temer" (cf. CHAVES NETO, 1978?, 1982). 
O companheiro de Caio Prado Jr. registrava ainda que, como aconteceu com a Revolução Francesa, o capitalismo americano também se desvirtuaria. Depois, ele iria expropriar os três quartos dos trabalhadores que, à hora da formação da nação, eram autossuficientes, enfraquecendo o igualitarismo tocquevilleano, ao qual em seu tempo Roosevelt ainda chamaria de "paz pela abundância" (idem).

Vejamos outras referências relativas à questão democrática. Ela já estava no artigo "Política de União Nacional" (1955) e se reafirmara em "Emancipação Nacional e Defesa da Constituição" (1956). No primeiro deles, o autor relançará a fórmula de união nacional (que havia motivado a controvérsia do fim do Estado Novo) como um movimento de conformação de uma força política que fosse capaz de sustentar uma "nova política econômica" que "proporcione à nossa indústria e à nossa agricultura os meios, não somente de suportar esses encargos - elevação dos salários em face de carestia - mas de neles encontrar novas possibilidades de desenvolvimento" (CHAVES NETO, 1955). Segundo se lê no texto, a concentração das "forças nacionais democráticas em torno da Constituição" tinha por objetivo, desde logo, assegurar condições preliminares para que tivessem livre curso as reivindicações populares. Dizia ele que

Só a luta econômica processada dentro dos direitos para esse fim estabelecidos em nossa Constituição - o direito de greve, de sindicalização, de reunião - é que torna possível o constante ajuste dos salários segundo as condições variáveis da produção. Essa é a experiência democrática e a importância para a vida econômica de uma nação desses direitos que hoje em dia são conquistas da civilização e quotidianamente violados em nosso país pela polícia, transformada em defensora dos interesses das classes possuidoras (idem).

Esse artigo inaugural da Revista Brasiliense trazia ainda duas menções que vale mencionar. Numa primeira, Elias Chaves Neto valorizava a função progressiva dos ideais democráticos da Revolução Francesa ("aos quais o mundo deve o seu extraordinário progresso no século passado, e fundamentais para o desenvolvimento do nosso país"). Falando dessa força progressiva, o jornalista dizia que entre nós "A defesa da Constituição é, portanto, o ponto básico de uma política que visa pela união de todos os brasileiros a resolver os problemas dos quais depende a nossa prosperidade" (idem). Numa outra passagem o autor voltava a falar de uma espécie de americanismo "produtivista", já aludido. Cite-se o próprio autor:
Os homens de negócio são os primeiros a saber que o bom andamento dos seus negócios depende do alto poder aquisitivo das massas. É de Ford esse dito de que quando sentia necessidade de vender mais automóveis, aumentava o salário dos seus homens. Toda a história econômica dos Estados Unidos reside na compreensão deste fato. O presidente Lincoln assegurou durante decênios a prosperidade das indústrias do Este, locando nas terras além do Mississipi uma população de agricultores aos quais entregou gratuitamente 60 hectares de terras. (idem)

Em um texto escrito após a reação ao seu artigo "Política de União Nacional", mesmo com citações de autoridade (Stalin falando no XIX Congresso do PCUS como um "precursor" do XX Congresso; Kruschev admitindo a via parlamentar ao socialismo), Elias Chaves Neto ingressava na discussão já em curso em alguns partidos comunistas em torno da mudança do paradigma de 1917, especialmente no PCI. Em sua valorização de 1789 - "Isto não quer dizer que nada se tenha passado depois daquela revolução" -, ele explicava o ponto deste modo:

O que se quer dizer é que esses ideais de soberania nacional e das liberdades democráticas consignadas nas constituições burguesas oriundas da revolução francesa e norte-americana de fins do século dezoito conduzem à transformação revolucionária da sociedade (...) (CHAVES NETO, 1956a).

À sua maneira, Elias Chaves Neto voltava a defender a função progressiva das liberdades democráticas. Cite-se esta passagem:

Concordo plenamente com o Sr. Prestes de que a simples defesa da Constituição por si só não poderá dar solução alguma aos problemas brasileiros. É, porém, a condição necessária para esse fim. Trata-se de uma etapa. Mas é a etapa em que nos encontramos e é desta etapa que me ocupei em meu artigo, na qual ainda é possível falar em prosperidade para os nossos homens de negócios que compreenderem que têm lucros a realizar lutando pela industrialização do país, isto é, contra o imperialismo que nos quer reduzir a simples país agrícola, produtor de matérias-primas. (Idem). ${ }^{3}$

\footnotetext{
${ }^{3}$ Assim continuava aquele trecho: "No que acredito, como comunista, é que vencida esta etapa em que antes de mais nada temos de defender o nosso país da espoliação imperialista, com a ajuda dos homens de negócio que têm todo o interesse em contribuir para se criar uma
} 
Já no artigo "Sentido Dinâmico de Democracia", também de 1956, o amigo de Caio Prado Jr., por assim dizer, trazia a "questão democrática" para o Brasil. ${ }^{4}$ Os temas da democracia ("condição necessária para o progresso da nação") e da política econômica ("que faça da solução da miséria e atraso do nosso povo, e não dos lucros a realizar sobre os mesmos, o seu objetivo") aparecem nesse último texto conferindo um outro "sentido" à relação do chamado movimento nacionalista com as "instituições democráticas". O que diferenciava os textos de Chaves Neto da "sociologia da modernização" do PCB - que operava como um marco destinado a dar inteligibilidade à etapa "nacional e democrática" da revolução - era o sentido "construtivo" de uma política econômica que deveria implantar-se na sociedade realmente existente no país como programa, pelo menos inicial, da revolução brasileira que ele associava aos chamados "ideais democráticos". ${ }^{5}$

Coincidindo com outros pecebistas da época (Marco Antônio Coelho e Armênio Guedes), Elias Chaves Neto também começava a ver a democracia política como um processo de aperfeiçoamento da sociedade. Cite-se o autor: "É a aceitação plena desses direitos que firma o sentido atual da democracia, sentido dinâmico que permite a própria transformação da sociedade, a ponto de haver Palmiro Togliatti afirmado que era possível admitir-se a passagem para o socialismo por via parlamentar..." (CHAVES NETO, 1956b). No Brasil, a união das forças progressistas dever-se-ia processar "politicamente" "em torno da defesa das instituições democráticas". "A democracia se apresenta portanto através de um prisma novo no qual as reivindicações e os direitos dos trabalhadores passam a fazer parte integrante do regime" (idem). O "sentido dinâmico de democracia" se materializaria "no respeito à vontade popular, patente na legalidade de todos os partidos políticos através dos quais essa vontade tende a se

economia nacional e próspera, outros problemas se colocarão perante a nação - a passagem para o socialismo -, os quais, estes, exigirão uma solução revolucionária" (idem).

${ }^{4}$ Note-se que, quando Elias Chaves Neto fala de democracia, refere-se aos direitos de livre
Natem movimentação e representação, inclusive a legalização do seu PCB, a qual via como questão decisiva para o processo democratizante (idem).

${ }^{5}$ Como se verá mais adiante, no seu livro Diretrizes para uma Política Econômica Brasileira, Caio Prado concebe a "política econômica" como medidas destinadas à progressiva reestruturação da vida econômica, visando associar "produção" e "consumo", vale dizer, uma economia propriamente produtiva à maioria da população (PRADO JR., 1954). exprimir - notadamente, o Partido Comunista" (idem). ${ }^{6}$ Mesmo com o excesso militante, essa referência espelha o papel que à época o PCB começava a desempenhar, por meio de certo campo intelectual-político, na formação daquilo que Chaves Neto (seguindo o seu mestre) considerava estratégico: um "amplo movimento de opinião pública" - complete-se a ideia - "sem o qual a vida política não passará de uma agitação estéril, facilmente dominada pelas manobras dos homens de negócio que em nosso país representam os interesses estrangeiros, os quais aproveitam as dissensões de uma política personalista em que as questões ideológicas servem simplesmente para desviar a atenção do povo dos problemas concretos que o afetam" (idem).

No artigo "Legalidade Socialista", publicado à hora em que foram abertos no PCB os debates sobre o estalinismo - dos quais se ausentara Caio Prado Jr. -, Elias Chaves Neto faria sua leitura do XX Congresso do PCUS em meio à cultura marxista-leninista (nesse texto o autor falava de democracia burguesa, socialismo operário, etc.). Mas há outras passagens interessantes. Por exemplo, aquela em que ele aludia a um tema que também está nas análises políticas caiopradianas: a "defesa das instituições democráticas" como base para a formação de um movimento político "que resultará do fato de tomarem os brasileiros conhecimento dos seus problemas e das soluções que aos mesmos podem ser dadas segundo os seus interesses próprios, o seu modo de pensar e as suas aspirações" (CHAVES NETO, 1956c). Por aí o autor também se referia a um caminho ao socialismo que se apresentava no PCB por meio de textos dissidentes nos debates de 1956/57.

Elias Chaves Neto torna a buscar amparo em Kruschev, citando pronunciamentos posteriores ao XX Congresso, nos quais o secretário-geral do PCUS falava da hipótese da passagem ao socialismo por via não revolucionária; e novamente recorre a Togliatti e à tese dos comunistas italianos sobre a pluralidade de vias de acesso ao socialismo. Aliás, o autor observava que teria sido em função do seu modo inovador que os comunistas italianos se haviam mantido como partido politicamente

\footnotetext{
${ }^{6}$ Ele dizia ainda que, naquele momento, era "em torno das teses levantadas pelos comunistas que se agita(va) fundamentalmente a política do país". Isso quando a política "não é desviada por questões subalternas de interesses pequenos", aduzia repetindo Caio Prado Jr. Para este
} ponto, ver SANTOS, 2001. 
influente, inclusive por não se terem lançado no fim da guerra, em 1946, "desesperados ao poder e terem acolhido a via legal" (idem). Nessa mesma passagem, ele recordava os impasses criados pela política cnopista ${ }^{7}$ em 1945, quando o PCB, ao invés de continuar na articulação unitária das oposições daquela época, se isolara, "e preferiu seguir os políticos demagogos que se limitavam a lhe fazer promessas" (idem).

Em todo caso, se, por essas menções, é evidente a adesão de Elias Chaves Neto ao "caminho italiano ao socialismo", quer valorizando a função progressiva do constitucionalismo e da democracia política, quer tendo uma ideia gradualística da via de acesso ao socialismo, curiosamente não se vêm indícios de uma aproximação de Caio Prado Jr. com as tematizações do PCI, exceto naquele ponto da conduta "inteligente" (sic) e moderada do "grupo caiopradiano" se parecendo à dos comunistas italianos, por ocasião do fim do Estado Novo, quando o historiador persistiu na aliança com os liberais na luta pela redemocratização (CHAVES NETO, 1977).

Nos textos escritos por Elias Chaves Neto para o V Congresso de 1960, conjeturas como as anteriores precisam ser cautelosas. Já foi sugerida a presença de Caio Prado Jr. e Elias Chaves Neto naquele congresso como uma espécie de campo pecebista. ${ }^{8}$ Com luz própria, o historiador comparecera ao evento com sete artigos nos quais reapresentara sua versão da revolução brasileira, abrindo a controvérsia em dois pontos principais: no tema agrário e na questão da "apologia do capitalismo" que - como outros críticos da Tribuna de Debates congressual, ele também dizia - marcava as teses do Comitê Central. Por sua vez, Elias Chaves Neto escrevera os artigos "Planificação de Nossa Economia - Solução Nacionalista" e "A Contradição Principal - Base de uma Solução Marxista", compartilhando, muito mais que Caio Prado, os temas e os termos conceituais das teses oficiais. São textos nos quais o argumento caiopradiano trazido por Elias Chaves Neto aparece envolto pelas citações de autores da tradição, inclusive da própria maioria que hegemonizava o V Congresso.

${ }^{7}$ Relativo à CNOP (Comissão Nacional de Organização Partidária), movimento que, a partir da Conferência da Mantiqueira (1943), reestruturara o PCB, desarticulado com as prisões de 1940. ${ }^{8}$ Uma leitura da Tribuna de Debates do V Congresso aponta duas configurações diferenciadas mais importantes da maioria oficial: a tematização que se vê nos textos de Alberto Passos Guimarães e a leitura crítica das Teses oficiais que aparece nos artigos de Jacob Gorender. A ala oriunda do núcleo dirigente criticado na controvérsia de 1956/57, ainda ativa na Tribuna de Debates congressual, irá depois se afastar do PCB.
No segundo artigo, o diretor-responsável da Revista Brasiliense apresentava uma ideia de "contradição principal" em alternativa ao construto do nexo nação-imperialismo. Embora formulada em linguagem marxista-leninista, essa contradição principal era concebida segundo a teoria social exposta no prefácio marxiano à Contribuição da Crítica da Economia Política de 1859, em alusão a uma formação social "historicamente determinada". Ou seja, Elias Chaves Neto se referia à contradição entre a miserabilidade endêmica da população e o baixo nível das forças produtivas nacionais, conforme Caio Prado, como principal obstáculo interposto ao desenvolvimento nacional. ${ }^{9}$

Assim é que, alterando o "paradigma nacional-desenvolvimentista", o autor pretendia reabilitar o papel progressista das reivindicações populares, descobrindo-as do manto terceiro-mundista trazido pela tese da contradição nação/imperialismo (este como elemento externo), definida pela IC para contextos coloniais e semicoloniais. Elias Chaves Neto fundamentava a importância daquele nexo miserabilidade-forças produtivas apoiando-se nas proposições caiopradianas acerca do sentido da nossa colonização (colônia de produção) e do industrialismo débil e inconcluso.

Observe-se que a teoria caiopradiana da nossa gênese apontava, como traço da formação social brasileira, a dissociação entre a economia (produção da colônia voltada para fora) e o "consumo" (a maioria da população), esta última mobilizada como força de trabalho instrumental (ver a escravidão e a reprodução dos "restos escravistas" como marcas influentes na sua inorganicidade; e depois, no associativismo frágil). Tal dissociação (produção-consumo) - diversamente do industrialismo clássico perdura no tempo contemporâneo da nossa industrialização. Daí Caio Prado pensar a revolução brasileira segundo a fórmula da "conexão povo-mercado interno no emblema da Abolição" (cf. SANTOS, 2001). Os primeiros indícios desta fórmula já estão em Evolução política do Brasil (1933) e em Formação do Brasil contemporâneo (1942) e terão nova referência em História econômica do Brasil (1945) na alusão ao descompasso entre economia e política que então marcava nossa modernização. No texto de 1954, já citado, Diretrizes para uma Política Econômica Brasileira, a

${ }^{9}$ Caio Prado (e Elias Chaves Neto) mobilizavam o binômio forças produtivas-relações de produção tal como Marx e Engels apresentam de modo modelar no capítulo 1 de $O$ Manifesto do Partido Comunista. 
fórmula terá seu equacionamento referido a Keynes e à Cepal, ${ }^{10}$ sendo reapresentada de modo sucinto em A revolução brasileira (1966).

Com essa problematização, o historiador chegará a uma espécie de cânone "produtivista" com o qual proporia as duas grandes reestruturações da vida nacional: a da economia à base da mobilização produtiva do trabalho nacional plenamente livre (via sustentável para generalizar o progresso e a incorporação social) e a "reestruturação da nossa vida política" em moldes democráticos. Diverso dos países de industrialismo clássico, o Brasil tem uma vida política cuja trajetória sempre fora marcada pela debilidade dos grupos sociais e "agitação estéril" (para o tempo contemporâneo - 1945-1964 -, Caio Prado mencionava a ausência de "debates nacionais" e partidos ideológicos). ${ }^{11}$

Tudo indica que, por ocasião do debate congressual de 1960, Elias Chaves Neto fazia aquele "ajuste" na definição das contradições da revolução à maneira da operação que realizara Caio Prado Jr. ao resumir suas duas teorizações (colonização e industrialismo) na formulação da revolução brasileira. Com o conceito de revolução "agrária" e "nacional", o historiador visava se contrapor radicalmente ao excurso das contradições do V Congresso que subsumia a oposição capital-trabalho a uma sobredeterminação (nação $v s$. imperialismo) altamente invasiva. Por sua parte, o publicista procurava "atualizar", nos anos nacional-desenvolvimentistas da década de 1950, o tema da contradição capitalista. ${ }^{12}$ Com limitações, Chaves Neto teria

\footnotetext{
${ }^{10}$ Recusando a ânsia por "produção e produtividade", o historiador assim demarcava sua Economia marxista: "As minhas reservas são relativas ao destaque que lhes é dado, sem a consideração que a meu ver deveria ser preliminar, ou pelo menos conjunta e no mesmo plano, da questão do consumo e do mercado. No caso brasileiro, e entre os dois polos do mecanismo econômico, a produção e o consumo, a oferta e a demanda, escolheria o segundo como ponto de partida e baliza do assunto" (PRADO JR., 1954: 194).

${ }^{11}$ Em um dos seus últimos textos (no adendo ao livro de 1966, "Perspectivas de 1977"), há uma passagem interessante na qual Caio Prado se refere ao fim do regime militar. Lembrando nosso contraste com os casos clássicos (aqui, a classe econômica que se beneficiara da modernização não tratou de estimular a construção de uma institucionalidade democrática), dizia ele: "Uma democracia que significa essencialmente participação efetiva dos governados na ação e comportamento do governo, uma democracia só para a burguesia e os aspirantes a burguês, pretensão de muitos, não é realizável. Ou será de todos ou de ninguém; e se terá então um regime como este nosso em vigor, a experiência pela qual passamos faz isso suficientemente claro" (PRADO JR., 1966; 1978: 267).

${ }_{12}$ Paulo Sérgio Pinheiro também já observara neste sentido (PINHEIRO, 1982; CHAVES NETO, 1982).
}

iniciado, naqueles seus artigos publicados na Revista Brasiliense, um "equacionamento" do tema da oposição capital-trabalho - que Caio Prado radicava na história nacional - incorporando a questão da democracia política como um meio de reforma da sociedade. Mas perdera nos dois textos do V Congresso boa parte das intuições que extraíra das lições do XX Congresso do PCUS, sendo bem maior sua dependência ao pensamento então marcado pela teoria maoísta das contradições que perpassava as Teses congressuais de 1960.

Há no autor, em 1960, um certo retorno ao emblema "1945" (cf. SANTOS, 2001), isto é, quando faz referência ao tema dos "interesses da população" segundo os parâmetros da "política econômica" e da "democracia". Com esses parâmetros, Chaves Neto procurava diferenciar o pecebismo da fase nacionalista do modo de fazer política das "agitações" e "aventuras", ponto este último no qual insistira Caio Prado Jr. tanto na teorização da nossa formação como nas suas análises da política de aliança nacional-popular dos tempos mais contemporâneos.

Embora já não leve ao V Congresso o tema do constitucionalismo do pós-guerra ao modo dos seus primeiros artigos, Elias Chaves Neto traz agora a questão da oposição capital-trabalho, por assim dizer, para dentro da política de frente única, de maneira parecida à visão que Caio Prado Jr. tinha dessa contradição no contexto da redemocratização de 1945 (SANTOS, 2001). O jornalista afirmava que, ao invés de deixar embargar as vistas pela opacidade da contradição nação/imperialismo, o PCB devia sair da paralisia e trabalhar politicamente aquela contradição do capitalismo. Mesmo construído em um exercício incongruente em vários pontos, o argumento de Chaves Neto vinha em favor de uma mudança no eixo da práxis popular deste modo: o campo de atuação prioritária do PCB, dizia ele, deveria ser buscar solução para os problemas imediatos, em lugar de se guiar pela especulação de qual seria o papel das massas como classes da revolução, mesmo que sua mobilização fosse pensada em nome de uma revolução definida por etapas e transições.

Elias Chaves Neto falava desse caminho como o único meio capaz de "arrastar a nação à luta anti-imperialista, condição necessária para a solução daqueles problemas" (CHAVES NETO, 1960b). O autor recorria à ideia de contradição (são citados Stalin e Mao Tse-Tung), falando de "complexidade de contradições", procurando mostrar que o analista que privilegiasse 
apenas a oposição nação-imperialismo obteria uma compreensão muito limitada da situação nacional, uma vez que, no caso brasileiro, a ação do capital estrangeiro não defrontava a nação contra um invasor vindo de fora, sendo várias as conexões que tecera ao se instalar no país e muitos eram os seus apoios entre setores nacionais, os quais nem por isso deveriam ser qualificados de "meros agentes" do imperialismo. Leem-se ali alusões a "caminhos mais complexos" ("o que existe, sim, são contradições entre o imperialismo e diferentes classes da nação (...)"; o autor dizendo ainda:

São grandes esses setores. Mas a unidade nacional, que justificasse falar em contradição entre o imperialismo e uma nação, só se verifica em caso de guerra de agressão, quando no dizer de Mao Tse-Tung, em seu trabalho Em torno da contradição, suas diferentes classes, com exceção de um pequeno punhado de traidores à nação, podem unir-se provisoriamente na guerra nacional contra o imperialismo (idem).

O autor fazia um exercício simples para desconstruir o modelo pecebista daquela época. Eis aqui o argumento: só naquele caso extremo de invasão militar era que se poderia falar de uma contradição principal tensionando toda a formação social, de modo que a ela as demais contradições deviam se referir. E, mesmo no exemplo chinês, não era a contradição capital-trabalho que se subordinava àquele tipo de lógica sobredeterminante, mas a oposição entre o regime feudal e as massas populares. Era essa última contradição que recebia o impacto da ocupação do território por um elemento externo (a força militar japonesa), vivendo o país um enorme constrangimento que perpassava por todas as classes e grupos sociais, em suma, que lhe abafava a existência como nação.

Vê-se no artigo que Elias Chaves Neto convergia com alguns renovadores do debate pecebista de 1956/57 quanto ao reconhecimento da industrialização pós-30 como um dado estratégico que seria preciso trazer para a formulação da orientação comunista. Esses renovadores insistiam que os eventos de agosto de 1954 haviam posto na ordem do dia a exigência de uma nova ideia de frente única que levasse em conta a pluralização de uma sociedade sob impulso desenvolvimentista e os atores realmente existentes na cena nacional. Ou seja, os que se haviam mobilizado para interditar o caminho do golpe de Estado após o suicídio de Getúlio, atores diferentes do esquema frentista do PCB. Se esses pecebistas reclamavam da ideia simplista de "expulsão do imperialismo" do Manifesto de Agosto de 1950 e das resoluções do IV Congresso realizado no final de 1954, Elias Chaves Neto ainda via o espírito desse último congresso conservado nas Teses do $\mathrm{V}$ Congresso de 1960 (idem). Segundo o autor, o simplismo da contradição naçãoimperialismo estava na forma de descrever a estrutura social, atribuindo conduta anti-imperialista a classes sociais, supondo que a ação política dos atores guiava-se diretamente pelo interesse que lhes era próprio, revelando, como ele mesmo dizia, um forte viés de "liberalismo econômico" nesta maneira voluntarista de ver as coisas (idem). Ele também aludia ao modo como era formulada nas Teses a "segunda contradição fundamental" - a que opunha as forças produtivas em crescimento ao monopólio da terra -, chamando a atenção para o fato de que, posta em chave orientalista, ela se tornava mero subproduto da teoria da feudalidade clássica, como nos velhos documentos pecebistas da passagem para a década de 1950 . O ponto prático que Elias Chaves Neto procurava extrair dessa controvérsia bizarra vinha por conta de que aquela visão induzia à ideia de que existiam duas lutas paralelas, a nacional-anti-imperialista e a agrária e antifeudal. O jornalista observava ainda que, montada segundo a oposição nação-imperialismo, a orientação pecebista oficial se mostrava mais confusa quando o analista levava em conta o alheamento da massa popular em relação à luta nacionalista que tinha lugar naquele momento (idem).

Fechando o argumento construído com peças da teoria das contradições, Elias Chaves Neto se valia das teses caiopradianas. Ele dizia que, para romper aquela forma de descrever e fundir os processos urbano e agrário, seria preciso colocar o problema "de maneira inteiramente diferente", conferir-lhe uma "solução marxista", isto é, caracterizar a formação social a partir da contradição básica entre forças produtivas e relações de produção. Seria do ângulo dessa "contradição genérica" de todo processo histórico (o autor citava $O$ manifesto comunista) que se entenderia o sentido da contradição entre "latifundiários e a massa camponesa". $\mathrm{Na}$ etapa do desenvolvimento da sociedade brasileira que se vivia, esta última era a oposição que limitava o crescimento das forças produtivas nacionais. Ou seja, no sentido que lhe dava Caio Prado Jr.: de um entrave em razão do baixo nível de vida da maioria da população, em larga medida localizada no mundo rural, e em função do industrialismo de pouca incorporação social, nas cidades. Seguindo o mestre, Elias Chaves Neto afirmava que a contradição capitalista ganhava significado específico no contexto daquele tipo de dualismo, e assim a definia sob formulação marxista-leninista: 
(...) Intimamente ligada a esta contradição principal (referia-se à principalidade da contradição "agrária" no sentido da ideia de "revolução agrária e nacional" caiopradiana), que desempenha o papel de dominante, está a contradição entre o proletariado e a burguesia. A natureza destas duas contradições é a mesma, fato do qual decorre naturalmente a aliança destas duas classes na luta pela sua libertação econômica, sob a direção do proletariado em virtude de esta classe representar uma etapa mais avançada no desenvolvimento da sociedade humana (idem).

Em meados de 1963, Elias Chaves Neto publicou um outro texto, "Revolução Democrática", no qual aduzia observações que realçam mais alguns traços do "grupo" pecebista. Dizia esse autor de muitos dos editoriais-assinados da Revista Brasiliense que, por exemplo, do bloco heterogêneo que se agrupava em torno das reformas de base, devia participar como "elemento ativo" uma burguesia industrial "esclarecida". Explicava que, mesmo compartilhando interesses com o latifúndio (do qual dependiam muitos de seus negócios) e mantendo relações com o imperialismo ("com uma grande diversidade de interesses" entre si), esses burgueses poderiam vir a gerar e a se envolver nas "diferentes correntes de opinião que se refletem em nossa vida política” (CHAVES NETO, 1963a). $\mathrm{O}$ autor entendia o processo em curso naquele pré-64 como um processo que - sem ser uma "revolução" - poderia obter êxito e as reformas de base tornarem-se reformas de "interesse nacional", à medida que, no seu próprio dizer (truístico), elas encarnassem a ideia de medidas reestruturadoras do industrialismo, a partir da elevação do nível de vida da "massa popular, particularmente da massa camponesa". Como dizia o editor da Revista Brasiliense, tratava-se de por em marcha uma política econômica nacionalista que revertesse o sentido da "revolução desenvolvimentista" de Juscelino Kubitschek, dando sequência à virada que significara a formação do governo João Goulart em 1961, apesar da tendência à demagogia (sic) do presidente da República (idem).

Em relação à questão do imperialismo propriamente dito, nesse artigo o autor novamente se voltava para o PCI, referindo-se agora ao significado que os comunistas italianos atribuíam à mobilização sindical que tinha lugar na Europa daqueles anos 1960, "aceitando a evolução da sociedade capitalista", mas também ensejando o controle das organizações gigantes através de uma fórmula que seria uma espécie de "Estado Nacional, sob a hegemonia do proletariado" (idem). Fazendo a comparação, Elias Chaves Neto dizia ser necessário aqui reconhecer que a reorientação que experimentara a economia durante a "revolução" pró-monopolista de Juscelino também criara no país uma nova situação e que ela impunha conferir "sentido novo" à luta anti-imperialista; um sentido que não apenas implicava medidas para fomentar "o surto dos negócios nacionais", como também o controle do governo sobre os monopólios, "e operá-los em favor do interesse do povo" (idem).

Lê-se ainda no referido texto uma alusão ao modo como aquela experiência operária valorizada pelo PCI colocava a problemática da fusão do tema da democracia com o socialismo. Elias Chaves Neto chegava a citar um artigo de Valetino Gerratana daquele tempo, no qual este intelectual, explicando o pensamento dos comunistas italianos no pós-XX Congresso, falava de um novo caminho de "progresso democrático em direção ao socialismo". Embora não haja em Elias Chaves Neto um excurso "mais político" como os da "tática das soluções positivas" e da "via pacífica", a ideia caiopradiana de "política econômica" que o intérprete de Caio Prado Jr. trazia para dentro do PCB daquela época encerrava o sentido de um continuum de medidas parciais que progrediriam até se converterem em um processo revolucionário (as duas "grandes reestruturações").

De qualquer modo, a "revolução democrática" de que falava Elias Chaves Neto naquele seu artigo não seria uma revolução em dois tempos, mas um processo progressivo movido por um conglomerado pluriclassista reunido em torno de dois objetivos estratégicos: a erradicação da miséria das massas camponesas (a "maioria da população", a rigor, as massas nacionais, "estruturalmente" empobrecidas) e o controle dos trusts internacionais. Como ele próprio dizia, fazendo a sua leitura das reflexões que tiveram lugar no PCI após o XX Congresso do PCUS:

Não se trata de uma revolução burguesa seguida de uma revolução socialista, mas de um movimento único de democratização do país em progresso para o socialismo (idem).

Observe-se que essa proposição verbalizada por Elias Chaves Neto ainda era imprecisa. A ideia de revolução democrática reúne passagens formulativas que não se completariam no autor. Elas fazem parte de um construto que se visibiliza em trechos dos artigos que o jornalista e, principalmente, o intelectual Caio Prado Jr. (este, sim, portador de uma obra 
estratégica para tanto) publicam na Revista Brasiliense; em todo caso, são passagens de um movimento que, como o dos dissidentes de 1956/57, de certo modo também iriam influenciar algumas formulações do PCB no pré-64.

Com efeito, a nova presença do "grupo" caiopradiano, a partir da Revista Brasiliense, vai ser notada na práxis agrária do $\mathrm{PCB}$, à medida que o Partido Comunista evolui para o associativismo rural de tipo sindical e, à maneira marxista-leninista, também incorpora a tese das "reformas parciais" como peça-chave de uma nova concepção de revolução por meio de reformas. Esta ideia de reformas graduais tem exemplo já no tempo da atuação de Caio Prado Jr. na Assembleia Constituinte de São Paulo, em 1947, reaparece na monografia de 1954 (Diretrizes para uma Política Econômica Brasileira) e, durante as discussões sobre o estalinismo, na citada "tática das soluções positivas", depois de 1959, afirmando-se em textos pecebistas. Mesmo sem reconhecer um pertencimento formal ao construto caiopradiano, finalmente, vai ser por meio dessa concepção de "reformas parciais" que os formuladores do PCB perfilarão o reformismo deste partido. Será vista como a mais consentânea com a ideia de sucessividade de governos nacional-democráticos que se afirmara no PCB a partir da experiência posterior à morte de Getúlio, particularmente com a Declaração de Março de 1958.

Quanto à valorização do constitucionalismo de Elias Chaves Neto, este tema será vivido pelo PCB como um caminho de pedras, que vai desde a virada na conduta dos comunistas - de adversários do "governo de traição nacional" de Getúlio, antes do suicídio, a tributário das alianças antigolpistas no imediato pós-54 - até à sua completa identidade com a frente democrática durante o regime militar. Poder-se-ia dizer que, depois de 1954, as ideias de progressividade da política econômica e de governos pluriclassistas (ver Declaração de Março) adquirem consistência com a questão da democracia. Questão democrática que, por um lado, era trazida por Chaves Neto do XX Congresso do PCUS e do PCI, e que, por outro, também provinha dos temas da antiestagnação e da frente única real, tal como chegavam dos debates de 1956/57 (SANTOS, 1988). Esses temas continuaram no tempo nacionaldesenvolvimentista, até o próprio PCB acrisolar elementos de uma nova mentalidade, após o golpe de 1964, notadamente a partir da sua vida no contexto do MDB, passagem para a qual ajudaria o clima intelectual de uma nova publicação - a Revista Civilização Brasileira. O PCB caminhava em direção a uma outra cultura política, ao dar vida a uma espécie de redimensionamento da sua política de frente democrática, como se vê em alguns documentos do Comitê Central no exílio e, sobremaneira, pode-se ler na ensaística dos chamados eurocomunistas brasileiros. Diz-se-ia, recordando o constitucionalismo do contexto de 1945 (valorizado por Elias Chaves Neto e Caio Prado), que a experiência do PCB na luta pelas liberdades democráticas durante a resistência ao regime de 1964 constitui o grande "influxo" da vida prática que estimula o aggionarmento da sua orientação nos últimos anos de vida.

Certamente os artigos de Elias Chaves Neto, aqui resenhados, constituem uma movimentação que não teria plena passagem no $\mathrm{PCB}$, mesmo que o jornalista com ele compartilhasse a mesma linguagem. Seria ainda mais difícil esperar que sobreviesse em seu partido acolhida ao próprio Caio Prado Jr. quando este operava na zona gris da "questão do método" tentando compreender a dialética da nossa formação social a partir do nexo passado-presente. O seu marxismo - diferenciado pelo significado substancial que tinham seus chamados deslizes (circulacionismo, idealismo) - não era, afinal, toda uma raison d'être para o historiador intérprete do Brasil. A ideologia do socialismo real à parte, muito mais do que resultado de uma defesa como um fim em si, o marxismo caiopradiano, que é um marxismo político, referencia-se e se afirma nas dissertações sobre a contemporaneidade brasileira, assistidas pelo método marxista, como o próprio historiador propõe, refeito pelos temas do circulacionismo e do "produtivismo" (SANTOS, 2001). Aí estava a raiz da chamada "ausência" de Caio Prado da política corrente. Enquanto o circulacionismo sempre foi visto como ponto metodológico controverso da sua interpretação do Brasil, o "produtivismo" ainda não tem sido relevado como questão central, a não ser para criticar o autor por dois grandes "equívocos" que, a rigor, são pontos essenciais da sua publicística tecida ao longo do tempo: a) a ideia de uma revolução capitalista à Welfare State exposta em A Revolução Brasileira (cf. FERNANDES, 1968) e b) e o que seria a redução do programa revolucionário a uma "revolução agrária trabalhista", que também é defendida por Caio Prado Jr., nesse livro de 1966, como questão estratégica.

\section{Referências bibliográficas}

BASTOS, Abguar. “Apresentação" da Revista Brasiliense n. 1, set./out. de 1955. 
CHAVES NETO, Elias. "Política de União Nacional", in: Revista Brasiliense n. 1, set./out. 1955 .

"Emancipação Nacional e Defesa da Constituição", in: Revista Brasiliense n. 5, mai./jun. 1956a.

"Sentido Dinâmico de Democracia", in: Revista Brasiliense n. 7, set./out. $1956 \mathrm{~b}$.

“Legalidade Socialista", in: Revista Brasiliense n. 8, nov./ dez. 1956c.

"Planificação de Nossa Economia - Solução Nacionalista", in: Novos Rumos, 3 a 9/06/1960a.

"A Contradição Principal - Base de uma Solução Marxista", in: Novos Rumos, 24 a 30/60b.

"Revolução Democrática", in: Revista Brasiliense n. 48, jul./ ago., 1963a.

"Medidas Concretas", in: Revista Brasiliense n. 50, nov./dez. $1963 \mathrm{~b}$.

Minha vida e as lutas de meu tempo. São Paulo: Alfa-Ômega, 1977.

"A Grande Revolução" (1978?), in: CHAVES NETO, Elias. Sentido Dinâmico de Democracia, São Paulo, Brasiliense, 1982.

COELHO, Marco Antônio. “A Tática das Soluções Positivas”, in: Novos Rumos, 29 de julho a 4 de agosto de 1960.

FERNANDES, Florestan. "Caio Prado não disse tudo", in: Jornal da Senzala, n. 1, jan./fev. 1968 (republicado sob o título "Sobre a Revolução Brasileira", in: F. FERNANDES, F. Brasil em compasso de espera, São Paulo, 1989).

JAGUARIBE, Hélio. A Filosofia no Brasil. Rio de Janeiro: Iseb, 1952; 1957.

MALTA, César. "A 'Revolução Brasileira' de Caio Prado Jr.” In: Revista Civilização Brasileira n. 9/10, set./nov. 1966.

PINHEIRO, Paulo Sérgio. "Introdução" a CHAVES NETO, Elias. Sentido Dinâmico da Democracia, São Paulo: Brasiliense, 1982.
PRADO JR. Caio. Diretrizes para uma Política Econômica Brasileira. São Paulo: Urupês, 1954.

. A Revolução Brasileira. São Paulo: Brasiliense: 1966 (as citações são da 6a. edição, 1978).

. Dissertações sobre a Revolução Brasileira, Brasília-São Paulo: Fundação Astrojildo Pereira e Brasiliense, 2007.

PRESTES, Luiz Carlos. "É Necessário Combater e Desmascarar os Defensores e Porta-vozes do Nacional-reformismo", in: Voz Operária, 28/04/56.

SANTOS, Raimundo. A Segunda Renovação Pecebista. Reflexos do XX Congresso do PCUS no PCB (1956-57). Belo Horizonte: Oficina de Livros, 1988.

Caio Prado Jr. na Cultura Política Brasileira. Rio de Janeiro: Faperj-Maud, 2001.

. Agraristas Políticos Brasileiros. Brasília: NEAD-FAP, 2007. 


\section{PARTE \\ NOVOS TEMPOS E OUTROS DESAFIOS}

\section{A IMPOrTânCIA da TRADIÇÃo PECEBISTA}

$\mathrm{R}$ ecordar a nossa esquerda histórica - o PCB - não constitui exercício extemporâneo. Para além do lugar que ocupam na história nacional, os comunistas do PCB deixaram várias contribuições para o pensamento de esquerda no Brasil, dentre elas, a mais importante é a da valorização da política e da democracia representativa no campo dos nossos agrupamentos de orientação marxista. Sua lembrança alude a traços constitutivos da nossa cultura política reformista que merecem ser evocado nestes tempos do segundo governo liderado por Luiz Inácio Lula da Silva. Vivemos dias em que tem curso um profundo processo de enfraquecimento do Congresso Nacional e dos partidos políticos e não são poucas as verbalizações de apelo populista igualmente corrosivas do valor do Estado democrático de Direito.

Ainda que não tenham elaborado um corpus intelectual, como, por exemplo, o PCI, na sua trajetória contemporânea rumo à democracia, os comunistas brasileiros proporcionaram às demais esquerdas um estilo de pensar e agir que poderíamos chamar de pecebismo. Trata-se de um modo de ser politicista - lembrando aqui em registro positivo um termo que já foi usado para desqualificar o PCB -, estilo construído num campo de esquerda em permanente busca do domínio das circunstâncias com as quais se deparavam os seus filiados. Este empenho foi estimulado pela boa intuição que marcou o Partidão, principalmente áreas do seu núcleo dirigente, dividido entre a orientação doutrinária e a realidade na qual os comunistas eram chamados a operar com previsão e perspectiva. $\mathrm{O}$ pecebismo expressa a propensão dos comunistas a compreender o sentido das conjunturas e a equacionar os requerimentos postos às esquerdas brasileiras. Circunstâncias que delas exigiam intervenção eficaz em um país cujo melhoramento dependia - como hoje depende - da sua democratização política.

Recolhido em documentos oficiais por meio de passagens às vezes ambivalentes - após embates entre ortodoxia e inovação, conciliações e fraturas -, esse custoso empenho para compreender o Brasil visava dotar os militantes de uma "linha política" geral que os habilitasse não só a intervir no mundo efetivo como ainda a avaliar as consequências dos seus atos segundo textos divulgados na imprensa partidária. Trata-se de um estilo vivido custosamente à margem da sua filiação internacional marxistaleninista, delimitado do seu forte vínculo com o socialismo real e a URSS.

Podemos localizar os antecedentes desse pecebismo bem no começo dos anos 1950, quando os comunistas dão os primeiros passos rumo a uma atuação aberta na superfície da vida sindical, após os exasperados anos da Guerra Fria.

Essa abertura se dava tanto em relação ao sindicalismo urbano então existente no país como ao mundo rural, no qual o PCB começou a fundar os sindicatos de assalariados e semiassalariados visando uma mobilização ampla que alcançasse os camponeses. No entanto, com tais sindicatos e a União dos Lavradores e Trabalhadores Agrícolas do Brasil (Ultab), terminariam por estruturar, em 1963, a rede associativa da Confederação Nacional dos Trabalhadores na Agricultura (Contag), ao largo do território nacional.

O pecebismo contemporâneo aparece de modo mais visível no momento em que os comunistas reencontraram a política propriamente dita na sequência do 24 de agosto de 1954. Foi quando o PCB se aliou a outras correntes gravitantes no mundo partidário real em defesa da Constituição de 1946, em luta contra a interrupção do processo de descompressão política que se afirmava naquela época. Depois, essa militância na frente única antigolpista formada em resposta aos eventos daqueles anos 1950 tornar-seia vocação, cada vez mais esta tática unitária sendo apresentada em elaborações pecebistas como um valor fundamental.

Em tanto prática, esse pecebismo dos comunistas, sobremaneira no pós-64, foi de muita responsabilidade e lucidez, como certa vez disse Hélio Jaguaribe, observando que a teoria que o referenciava não lhe era homóloga (cf. MARÇAL BRANDÃO, 1992). No entanto, como construção políticointelectual, o PCB teve épocas em que produziu boas elaborações, como no primeiro grande momento renovador ocorrido entre os anos 1956-58, do qual surgiu, com o apoio de Prestes, a Declaração de Março de 1958, texto anunciador da "nova política" com a qual o Comitê Central encerrou a controvérsia sobre o stalinismo e procurou consolidar a propensão dos comunistas a interferir na vida nacional. A defesa permanente e a apreciação das liberdades, bem visíveis durante o regime de 1964 na 
postura de frente democrática e na contínua busca de atuação nas instituições, no associativismo legal e em particular nas eleições, por mais limitados que estivessem, evidenciam a importância que os comunistas atribuíam à democracia representativa.

Esse pecebismo contemporâneo - como o emedebismo acrisolado nos anos da resistência ao autoritarismo - forjou um tipo de atuação influenciado por valores democráticos e particularmente por condutas unitárias construtivas bem características do PCB desses tempos duros.

Em relação ao nexo reformismo e democracia política - o outro grande tema em que há contribuição dos $\operatorname{comunistas}^{1}-$, observemos que há uma tradição em equacionar as questões da economia no terreno da política. Esta marca se torna cada vez mais clara à medida que os publicistas do PCB buscam explicitar as imagens de Brasil que lastreiam a orientação partidária, como por ocasião da Declaração de Março de 1958 e entre meados da década de 1970 e os inícios da redemocratização. Este era o tempo em que parte do Comitê Central pecebista vivera no exílio, no momento do eurocomunismo. Foi quando jovens comunistas ensaiaram uma reinterpretação da nossa formação social a partir do nexo prussianismo-revolução passiva. ${ }^{2}$ Esta tentativa intelectual convergia com a movimentação de veteranos dirigentes, como Armênio Guedes, que retomavam a linha de valorização da democracia política como ponto de referência para a renovação da esquerda histórica brasileira naquele começo da década de 1980.

Mesmo tendo dado passos decisivos, como nenhum outro agrupamento de esquerda, em direção à política e à valorização da democracia, o PCB não conseguiu traduzir a "questão democrática" - lembrando aqui esta expressão dos anos do eurocomunismo - em termos de uma elaboração que valorizasse o Estado democrático de direito como único terreno no qual poderia ter curso sustentável a reforma da sociedade brasileira. No campo marxista, este passo exigia a prévia discussão do conceito-chave do socialismo - a

hegemonia -, como se viu no debate empreendido pelo PCI na segunda metade da década de 1970, quando este partido foi interpelado, especialmente por Bobbio, a propósito da tese marxiana da extinção da política em decorrência da homogeneização da nova sociedade. Esta controvérsia duraria anos no PCI, inclusive perpassou as mutações do campo alargado PCI-PDSDS. Ela só se "concluiria” bem depois, digamos assim, agora há pouco, em áreas que ainda guardam raízes no antigo PCI (e no pensamento de Togliatti-Gramsci, como disse Giuseppe Vacca, recentemente no Rio de Janeiro) e que hoje integram o Partito Democratico (PD) italiano, criado não faz muito tempo.

Nos últimos tempos do seu PCB, quando o comunismo e a URSS se esgotaram, no início dos anos 1990, os pecebistas não avançaram naquela discussão. Pode-se dizer que não converteram a valorização da democracia política numa aceitação do Estado democrático de Direito sem nenhum tipo de reserva e fundamentada, como há muito vem defendendo Jurgen Habermas como postura da esquerda democrática. No entanto, no campo que ainda tem o PCB como referência, tanto entre intelectuais independentes como na esfera propriamente partidária (o PPS e sua área de influência), notam-se movimentações abertas ao tema da pluralidade da vida nacional; abertura considerada decisiva não só para balizar o agir no momento presente como para se pensar o país no longo prazo. Na intelectualidade há registros que problematizam a diversidade da nossa formação social como valor permanente e vantagem estratégica.

$\mathrm{Na}$ área política, certos movimentos com vistas à próxima eleição presidencial, como, por exemplo, as convergências partidárias defendidas pelo ex-senador Roberto Freire vão na direção do reconhecimento da importância de uma parte bem expressiva do mundo político hoje existente, com seus partidos de espectro social e ideológico variado.

Esse tipo de valorização do mundo político, lembrando a função de ponto de apoio que ele representou durante a resistência ao autoritarismo, constitui uma das condições fundamentais do pluralismo que ora vivemos sob o Estado democrático de direito. E, mesmo que agora esteja necessitando de renovação profunda, o nosso mundo político pode vir a ser a principal condição da vida democrática que temos. Isso se, de um lado, crescem entre nós as manifestações messiânicas e se, de outro, se não se afirma entre áreas dos partidos - inclusive do PT e do PMDB - a ideia de se formar um campo 
reformista radicalmente comprometido com a vigência da democracia política no curto e longo termo.

Hoje, ainda são poucas as expressões elaborativas nos círculos intelectuais próximos ao PPS. As próprias iniciativas político-eleitorais, como as de Roberto Freire, não revelam maior sustentação em teses dos últimos tempos do PCB ou em outros textos sucedâneos importantes. Em todo caso, nessas duas áreas-chave, até agora, não foi anunciada disposição de se passar da fórmula oitocentista da aliança entre "partidos de esquerda" e "partidos de centro" - fórmula que aos olhos do antigo campo pecebista resumia as possibilidades do reformismo brasileiro contemporâneo - rumo a um novo tipo de unidade baseada na convergência e fusão de elementos analíticos das nossas realidades atuais e valores oriundos de mais de uma cultura democrático-reformista certamente existentes no país.

Esse novo caminho para suscitar e reunir forças renovadoras vem com a controvérsia que nos trazem outros ambientes da esquerda democrática, principalmente o PD italiano, que fala de um processo unitário diverso da estratégia de alianças do passado. Vê-se em textos desse partido que agora as convergências políticas são pensadas como uniões duradouras que perpassem a um campo mudancista pluralizado, potencialidade nova que lhe permita inovar na elaboração de um projeto de melhoria da vida nacional nas condições do globalismo de hoje e da crise mundial ora em curso. Esse impulso inovador tem sido o sentido principal das alianças partidárias e das reunificações com que se envolveu o PCI, desde os anos da tese berlingueriana do "compromisso histórico", proposta em 1973, logo após os acontecimentos sangrentos do Chile de Allende.

O objetivo estratégico de agora é o de que, com tal projeto, chamado pelo PD italiano de "aliança com o país", uma nova formação de esquerda democrática, assim criada, possa se expandir na aceitação do eleitorado, de maneira ampla e sustentável. O movimento ao redor do PD italiano parece bem delimitado da fórmula do passado: trata-se de uma política de alianças já não mais limitada à procura, por meios organizativo-partidários, de máxima força para combater inimigo, ou para realizar governo de uma corrente numericamente forte, mas propensa a exercer hegemonia e cooptação sobre os aliados convergentes.

Este novo movimento unitário tornou-se mais nítido à sequência das importantes vitórias da direita na Europa, no caso, após a última eleição de
Berlusconi na Itália. Relembremos ainda que ele advém no contexto da formação de governos messiânicos em outras partes, a América Latina e o Brasil incluídos. Agora, setores da esquerda democrática, em particular o Partito Democratico, referem-se a tal tipo de convergência como uma estratégia que dê vida política a um projeto de renovamento nacional, elaborado sem autossuficiência e reservas entre as correntes atraídas para o cometimento de buscar saída para a crise e avançar na renovação do país. Um tipo de concertação que, a partir das culturas políticas reunidas, suscite visões e valores capazes de mobilizar a maioria da população, ensejando uma nova formação político-partidária competitiva eleitoralmente por força do convencimento de um projeto exequível. Criar-se-iam, por este caminho, condições para converter o programa de "aliança com o país" em metas que possam vir a ser tanto apoiadas - vividas - pela sociedade, sob vigência plena do Estado democrático de Direito, como convertidas em ações de governo(s) constituído(s) por meio de eleições livres e democráticas.

\section{Referências bibliográficas}

MARÇAL BRANDÃO, Gildo. Capitalismo, Democracia e Comunismo, USP, tese de doutoramento, 1992.

VIANNA, Luiz Werneck. Liberalismo e Sindicato no Brasil. Rio de Janeiro: Paz e Terra, 1976.

. A Revolução Passiva - Iberismo e Americanismo no Brasil. Rio de Janeiro: Editora Revan, 1997. 


\section{APÊNDICE DA II PARTE: NOVOS TEMPOS E OUTROS DESAFIOS}

\section{PD ITALIANO, CRISE ECONÔMICA E INOVAÇão POLÍTICA}

$\mathrm{O}$ relatório apresentado por Walter Veltroni no encontro da Direção Nacional do Partito Democratico (PD) em 19 de dezembro de 2008, em Roma, constitui peça discursiva das mais emblemáticas da esquerda democrática destes nossos dias. O presidente do PD abre o texto afirmando que, para enfrentar a atual crise - "gerir a emergência, imaginando o futuro" - necessita-se de "muita e boa política". A crise chega à Itália, sob o governo de Berlusconi, um líder populista "em permanente campanha eleitoral". Escreve ainda Veltroni que, com seu incessante ativismo de "oposição à oposição", Berlusconi só contribui para corroer profundamente a "credibilidade moral da política", pondo a democracia italiana em "perigosa voragem". Esse tipo de popularidade, esclarece o dirigente excomunista, cada vez mais acentua o desencanto e a desilusão.

É nesse quadro que o PD se põe à prova. Veltroni menciona a origem do novo partido e suas promessas de inovação radical na política, na formapartido, no plano programático, bem como o compromisso de provocar descontinuidade na classe dirigente italiana. Lembrando que o principal antecessor do PD, o Partito Democratico della Sinistra (PDS), formado em momento intenso da globalização, a partir do PCI, não fugira dos desafios da nova conjuntura, agora, em nome do PD, Veltroni vem nos falar da atual circunstância de crise e também de um tempo promissor. Segundo ele, a alternativa com que ora se defronta a esquerda democrática na Itália se resume ao ultimato: "renovamento ou bancarrota". Sob forte tensão, o PD terá que mostrar que é capaz de acelerar a inovação - sobretudo política e programática -, condição sine qua non para servir ao seu país como ator decisivo nos novos tempos.

Assim como o PDS não vira a circunstância global passivamente, Veltroni, no seu relatório, registra que agora o PD tampouco está diante de uma conjuntura qualquer. Será necessário afastar o berlusconismo e o seu modelo, que é um modelo, esclarece ele, antes cultural do que econômico e político, no sentido de um modo de adaptar a Itália à hegemonia do pensamento neoconservador dos últimos trinta anos, posto em declínio irremediável pela crise econômica em andamento.

Em que termos o dirigente da esquerda italiana nos apresenta a circunstância que ora vivemos? "As crises são fases de transição, duras e dolorosas, das quais nunca se sai como se entrou: na forma e no modo de produção e desenvolvimento; nas relações de forças, sociais e políticas; nos modelos culturais, na hierarquia de valores." Recorda que da grande crise de 1929, sobretudo depois da Segunda Guerra, saímos com um grande compromisso entre capitalismo e democracia. Conhecemos o crescimento impulsionado pelo consumo de uma classe média em expansão (na qual entrava o mundo do trabalho, inclusive operário) e uma forte redução da desigualdade, graças a políticas salariais generosas e a fortes ações redistributivistas públicas. Vimos, então, uma rápida expansão do Estado Social.

A crise do petróleo e a estagflação dos anos 1970, continua Veltroni, obrigaram o Ocidente a mudar de rumo: fizeram-se grandes investimentos na inovação tecnológica; elevou-se a produtividade à custa dos postos de trabalho e do poder contratual dos sindicatos; a classe média se reduziu; as desigualdades voltaram a se alargar e a ascensão social se bloqueou, inclusive devido ao redimensionamento do Estado Social. Essa é a época em que se teoriza sobre a autossuficiência do mercado e se afirma o superpoder da finança sobre a economia real, "com graves consequências também para a democracia, forçada a renunciar a qualquer soberania sobre os fluxos de capital". Conhecemos, então, uma fase de crescimento econômico ao preço de grandes desequilíbrios e elevação da desigualdade.

Veltroni se refere a outros traços característicos dos anos subsequentes de globalização. Vimos novos protagonistas - "milhões de seres humanos" excluídos do desenvolvimento - saírem à superfície em busca de reconhecimento e lugar num mundo moderníssimo. Conhecemos, no século XXI, um desenvolvimento ao mesmo tempo impetuoso e insustentável. No plano global, tivemos um desenvolvimento marcado pelo debilitamento americano e a ascensão asiática; no plano ambiental, um desenvolvimento tensionado pelas consequências que a transferência do modelo ocidental aos países emergentes provocam no clima; no plano interno, o empobrecimento da classe média, em particular nos EUA, onde ela se endividaria buscando garantir casa, saúde e instrução. Essa é a época da pretensão americana de 
dirigir o mundo de modo unilateral, cujo paradoxo dramático se expressa na guerra contra o Iraque.

Veltroni resume o núcleo da sua narrativa dizendo que o "pântano iraquiano" e a crise financeira ora em curso despedaçaram a ilusão neoconservadora, dando passagem "a uma nova fase, a um novo paradigma de pensamento e a uma nova época política".

Nessa circunstância complexa, que ainda se configura, o povo americano, "com muita clarividência" - celebra Veltroni como um primeiro grande evento positivo -, elegeu Barack Obama. Ao invés de fechar-se defensivamente, a América pôs-se caminho à frente, sinalizando possibilidades para um novo multilateralismo nas relações internacionais, um novo New Deal, com base na reconstrução da classe média, e uma nova fase de igualdade social. Mesmo ainda estando em curso os desdobramentos da vitória de Obama registra Veltroni -, já cabe ao novo presidente abrir "simbolicamente" uma fase nova, "uma terceira fase do desenvolvimento humano".

Assim, a partir do binômio representado pela crise financeira e pela eleição americana, Veltroni fala de um tempo promissor, dizendo que estamos diante de uma "extraordinária oportunidade e também de uma lição para aprender e meditar". Segundo ele, na sociedade americana, a crise trouxe à tona o conflito social (por anos posto em segundo nível pelo uso ideológico das questões de raça, dos valores tradicionais, da segurança interna e externa), ativando o apoio ao programa eleitoral inovador de Obama. É como se a crise houvesse dissolvido a "névoa" que, por três décadas, levara setores populares e a classe média dos EUA a votar contra os próprios interesses e a favor de uma minoria privilegiada.

Veltroni retém da eleição de Obama esse último ponto, como tema de valor mais universal: é possível mudar a correlação de forças nas sociedades de estruturação altamente complexa. Se um processo desse tipo abre caminho novo nos EUA, nada impede que também possa ocorrer em outras formações "ocidentalizadas", aludindo-se aqui ao termo não geográfico de Gramsci. A lição americana mostra que a condição para mudar a correlação de forças na sociedade consiste "em recolocar, em primeiro plano, na competição política, a questão econômica e social, e oferecer a esta questão saída realista por meio de uma proposta de forte inovação política e programática”.
Com tal referência, Veltroni nos leva à questão da "vocação majoritária", operando um redimensionamento radical da questão da hegemonia, tema outrora clássico na esquerda. Para ele, agora essa questão não mais se funda na presunção arrogante da autossuficiência. $O$ ponto de partida de uma esquerda democrática que busca ser governo está na convicção de que as relações de forças eleitorais "não são um destino inelutável", mas também podem ser alteradas em profundidade, "se mudar a oferta política por meio da inovação da proposta que apresentamos ao país".

Veltroni deixa mais claro aquele tipo de visão não atávica, ao dizer que o empenho para mudar a disposição de forças com base na política democrática exige recusar as teses da vocação "de direita" da sociedade italiana e do "insuperável caráter minoritário" da esquerda. Significa romper com qualquer ideia naturalizada da correlação de forças e com a ideia de que os reformistas e democratas estão condenados a recorrer à "manobra política" e ao "jogo da aliança" como seus únicos meios para obter consensos majoritários: "O Partito Democratico nasceu com base no pressuposto contrário. Uma profunda inovação política e programática pode mudar, até mesmo significativamente, a orientação eleitoral dos italianos".

$\mathrm{O}$ dirigente se refere neste ponto à necessidade, por parte de sua formação partidária, de reconquistar parte dos consensos sob hegemonia da direita (construindo-se "uma grande aliança na sociedade italiana, uma aliança com o país"). Nesta passagem, ganha significado a proposição do renovamento da política e dos projetos programáticos, apresentada no relatório como diretriz geral do PD.

Exigindo "generosidade, paciência e tenacidade", certamente esse caminho passa por uma convergência política ("heterogênea"), construída não em termos de uma luta contra o adversário, segundo a velha fórmula novecentista de aliança entre "partidos de esquerda" e "partidos de centro". Esta fórmula não só é um projeto "incompatível” com o PD ("que é um partido de centro-esquerda"), como se tornou "anacrônica" por não conter "nenhuma potencialidade inovadora". A aliança a ser buscada é uma aliança para a inovação e a mudança, cuja credibilidade se afirma mediante testes de competência para governar. E isso só será possível, diz ainda o excomunista, se o PD souber demonstrar "capacidade expansiva", se não delegar a outros "a tarefa, que lhe é própria, de modificar as relações de 
forças políticas na sociedade italiana, por meio da mobilização de uma proposta renovadora e confiável".

No passado recente, outros líderes da "tradição do PCl", entre eles Massimo D'Alema, divisaram linhas de atuação - participando inclusive de governos reformistas de centro-esquerda - que estimulassem a generalização dos benefícios da globalização. Espelhando essa "tradição", por assim dizer continuada no nexo PDS-DS-PD, Veltroni também vê movimentos favoráveis forçando passagem nesta hora presente.

Com a crise da hegemonia do pensamento neoconservador, diz ele, pode-se afirmar o primado da política sobre a força e, depois da crise do unilateralismo, o multilateralismo como única via eficaz para o diálogo entre os povos, a paz e um desenvolvimento equilibrado e sustentável.

Veltroni chama a atenção para duas grandes percepções que se afirmam nos tempos conflituosos de hoje. De um lado, os perigos que pesam sobre o meio ambiente vêm impondo uma visão qualitativa do desenvolvimento, que faz da pesquisa tecnológica e de novas fontes energéticas o setor básico de uma "nova revolução industrial". De outro, cresce um segundo grande entendimento: o de que, para além da contraposição entre religião e razão, ganha força a ideia de uma sociedade pós-secular, na qual a dimensão pública da fé religiosa é reconhecida e chamada a dar contribuição aos laços sociais e à vitalidade da democracia, desde que reconhecida a autonomia da política e a laicidade das instituições.

No discurso aqui resumido em pontos bem gerais, o PD se propõe ser ator relevante na cena italiana de hoje ao se reivindicar possuidor de um projeto nascido com base em intuição mais cultural do que política. Projeto gestado quando se começou a perceber que o novo mundo em surgimento vulnerabilizava a velha cultura de esquerda do século XX, cancelando sua pretensão de autossuficiência. Tal circunstância exigia "um pensamento novo, novas categorias para ler a história e novo alfabeto para com ela dialogar". Requerimentos indispensáveis para afirmar - assim resume Veltroni a nova utopia - o empenho do campo político-partidário dos reformistas por uma "sociedade aberta, livre e igual", com o PD ostentando - em sua interação com outros protagonistas - completa e irrenunciável identidade com a meta da democracia, "o único sistema respeitoso da dignidade de todos os seres humanos". 